\title{
Analysis of the effects of soil-structure interaction in reinforced concrete wall buildings on shallow foundation
}

\section{Análise dos efeitos da interação solo-estrutura em edifícios de paredes de concreto sobre fundações superficiais}
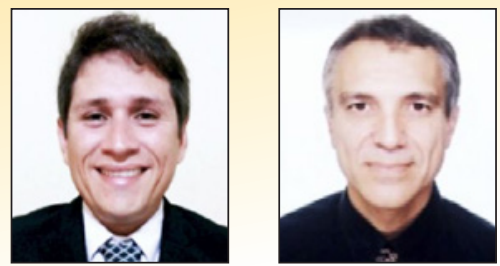

M. G. C. SANTOS a marcell.gustavo@hotmail.com

M. R. S. CORRÊA b marcio.correa@usp.br

\begin{abstract}
This paper presents a study of the effects caused by soil-structure interaction in reinforced concrete wall building on shallow foundation. It was verified the influence of displacements of supports on the redistribution of internal forces in the structural walls and in the redistribution of loads on the foundation. The superstructure was represented by shell finite elements and the soil-structure interaction was evaluated by iterative methods that consider the stiffness of the building, the soil heterogeneity and the group effect of foundation elements. An alternative model that considers the soil-structure interaction is adopted and the concrete walls are simulated by bar elements. The results indicate that the soil-structure interaction produces significant changes of the stress flow, with larger influences on the lower walls, as well as a tendency of settlements standardization and load migration to supports with smaller settlements.
\end{abstract}

Keywords: reinforced concrete wall building, structural analysis, shallow foundation, soil-structure interaction.

\section{Resumo}

Este artigo apresenta um estudo dos efeitos causados pela interação solo-estrutura em um edifício de paredes de concreto moldadas no local sobre fundações superficiais. Foi verificada a influência do deslocamento dos apoios na redistribuição dos esforços das paredes estruturais e dos carregamentos das fundações. A superestrutura foi discretizada em elementos finitos de casca e a interação solo-estrutura foi avaliada através de métodos iterativos, que consideram a rigidez da edificação, a heterogeneidade do solo e o efeito de grupo das fundações. Um modelo alternativo, em que a interação solo-estrutura é considerada de maneira simplificada e as paredes de concreto são discretizadas por elementos de barra, foi proposto e avaliado. Os resultados indicam que a interação solo-estrutura produz uma significativa modificação no fluxo de tensões, com maior influência nas paredes inferiores, bem como uma tendência de uniformização dos recalques e migração de carga para os apoios de menor recalque.

Palavras-chave: edifícios de paredes de concreto, análise estrutural, fundação superficial, interação solo-estrutura.

University of São Paulo, São Carlos School of Engineering, Department of Geotechnical Engineering São Carlos, SP, Brazil;

University of São Paulo, São Carlos School of Engineering, Department of Structural Engineering, São Carlos, SP, Brazil. 


\section{Introduction}

A Concrete wall is a rationalized construction system that offers the advantages of high-scale production, in which the structure and the sealing are formed by a single system. In a concrete wall system, the window frames and electrical, sanitary and hydraulic installations can be incorporated. All the walls and slabs of the same cycle are concreted in a single step. Due to the high degree of industrialization, a concrete wall system is presented as a viable alternative. This constructive system is recommended for buildings that need to be executed quickly and that have a short delivery deadline and/or high repetition rate.

Behavior and structural analysis of reinforced concrete wall buildings has been topic of research in Brazil (Nunes [1] and Bragum [2]). The Brazilian National Standards Organization (NBR 16055:2012 [3]) regulates the quality, enforcement procedure and structural analysis of reinforced concrete wall buildings.

Traditionally, in the behavior analysis of reinforced concrete wall buildings, fixed supports are considered. However, the settlement of the foundation causes the internal force redistribution in the structural elements. In short, the reinforced concrete wall system behavior is governed by superstructure, infrastructure and soil interaction. This mechanism is called soil-structure interaction (SSI) and has been the topic of many studies (Meyerhof [4], Chamecki [5], Goshy [6] and Gusmão [7]). Testoni [8 and 9] and Santos [10] discussed SSI in reinforced concrete wall buildings.

Despite recent research and the design code, advances are still needed in knowledge regarding the reinforced concrete wall building behavior and their analysis models. In this paper,

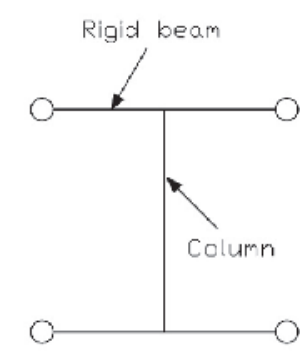

(a) Equivalent beam-column mode.

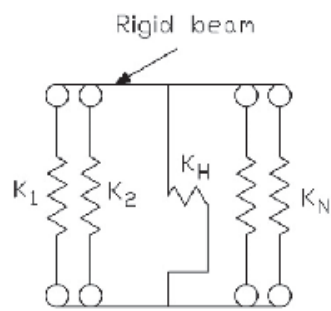

(d) Multiple vertical-line element rodel

\section{Figure 1}

Modeling wall methods (Source: adapted from Liu et al, 2010)
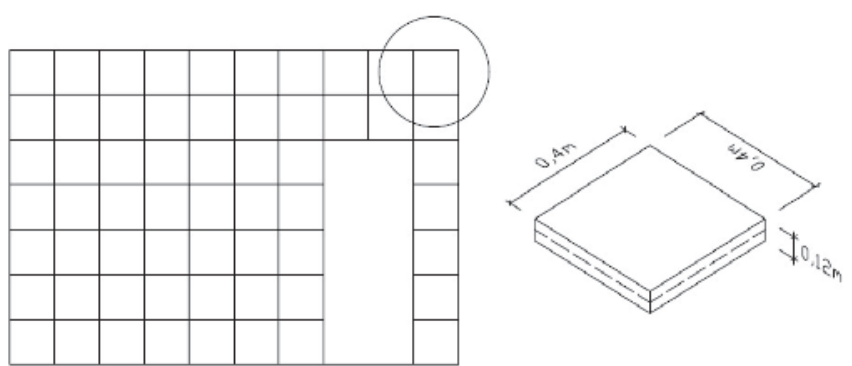

\section{Figure 2}

Discretization of the wall in shell elements

the procedures and results of an SSI analysis of a reinforced concrete wall building with 10 floors and a shallow foundation are presented.

\section{Numerical modeling of superstructure}

The numerical analysis of structural walls can be carried out using discrete or continuous techniques. The discrete procedure enables more flexibility because it is able to solve problems with varied geometry and loads. Liu et al. [11] shows three general methods for the wall structural analysis following a discrete technique, as shown in Figure 1.

In this paper, two types of superstructure discretization were used. In the first one, called the SHELL model, discretization by shell elements was adopted, as shown in Figure 1d. This model provides accurate results that were not obtained using the beam elements, e.g. the internal force flow in the walls and consequent migration of the load for the supports. However, laborious computational modeling and result analysis can make it unfeasible for the daily use of structural design. Therefore, using a simplified model is preferred.

A second type of superstructure discretization, called MIXED model, to analyse a simplified model was considered. This model adopted equivalent beam-column elements (Figure 1a) above the second floor. Taking into account the effects caused by SSI, the shell elements on the two lower floors were kept. The finite element method (FEM) was used adopting the SAP2000 software to carry out the numerical analysis of the study building. The material was considered as linear elastic behavior.

To discretize the wall in the SHELL model, four-node quadrilateral shell finite elements (Shell-thin) were used with dimensions of $0.4 \mathrm{~m} \times 0.4 \mathrm{~m}$ and 0.12 thickness, as shown in Figure 2. Braguim [2] made comparisons between meshes with $0.2 \mathrm{mx} 0.2 \mathrm{~m}$ and $0.4 \mathrm{~m} \times 0.4 \mathrm{~m}$ dimensions and concluded that the differences in the results are practically non-existent. In this paper, a prior analysis was carried out to evaluate the influence of the mesh discretization on the results of the study building. The $0.4 \mathrm{~m} \times 0.4 \mathrm{~m}$ mesh element presents similar results to more refined mesh and a lower computational cost. The floor slab was considered as a rigid planar diaphragm.

In the MIXED model, the walls are discretized by frame elements. This discretization was based on Yagui [12 and 13], where the walls are replaced by the plane frame formed by horizontal rigid beams and a flexible column. This frames are join by a rigid floor 


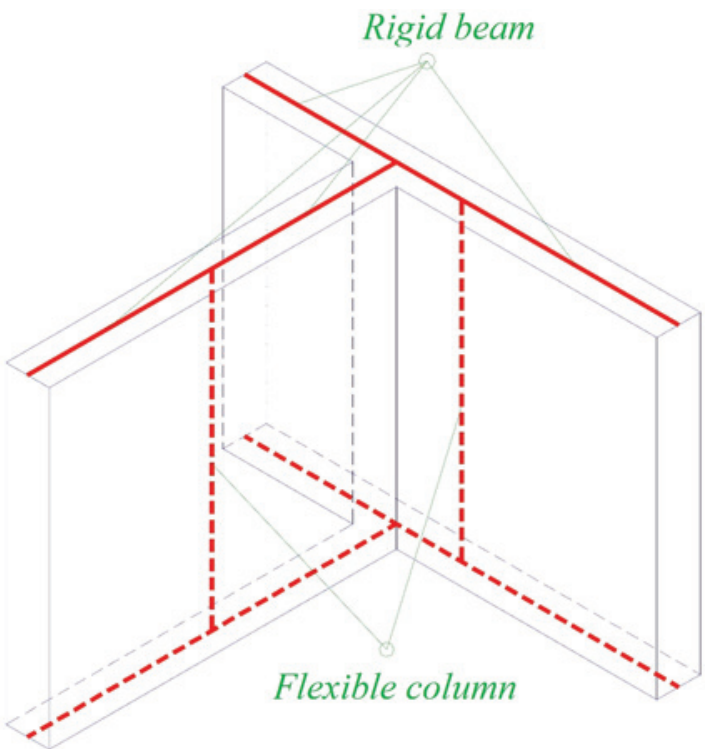

\section{Figure 3}

Discretization of the wall in frame elements (Source: Nascimento Neto, 1999)

slab (rigid planar diaphragm), forming a three-dimensional system. The columns must have the same geometric features as their respective walls and should be located in the geometric center of the walls. The walls are connected by a rigid horizontal beam and are applied on the floor level. Corrêa [14] recommends that the adopted value of beam rigidity is sufficiently large, as long as it does not disturb the numerical instability. In this paper, the Young's modulus value was multiplied by 100 , as applied in Testoni [8]. Figure 3 shows a schematic drawing of the equivalent beam-column element discretization. The connection between two rigid beams are considered joints, where the only vertical shear stress is only taken into account. In this model, door and window openings are considered as flexible beams of infinite axial rigidity as shown in Figure 4.

According to NBR 16055:2012 [3], the wall of the structural system can be represented by a linear element as long as the shear deformation is considered. Nascimento Neto [15] suggests a refinement of the model proposed by Yagui [12 and 13] to consider shear deformation in a simplified way. A shape factor of $c=1.2$ was used to
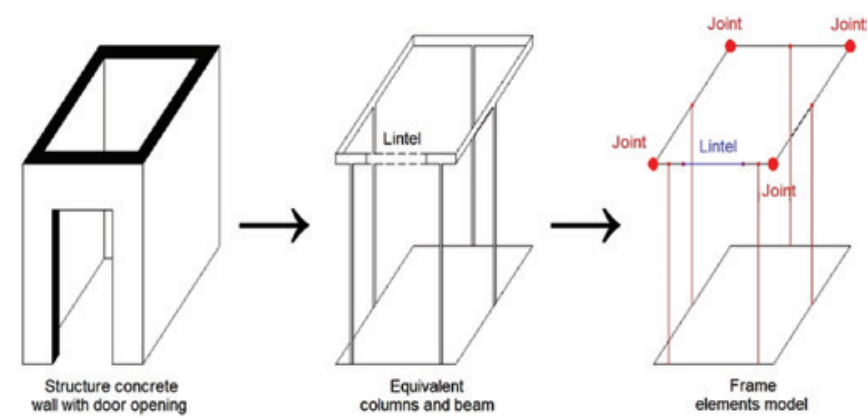

Figure 4

Representation of the lintels reduce the section area of the walls and determine the equivalent shear area $\left(A_{s}=A / C\right)$.

In the three-dimensional frame model proposed by Yagui [12 and 13 it is not possible to analyse the migration tendency of the load for the supports. Considering this behavior on the structural model, the walls of the first and second floor had to be discretized by shell elements, based on Nunes [1] and Testoni [8 and 9]. In this model, the first and second floors were discretized by a $0.2 \mathrm{~m} \times 0.2 \mathrm{~m}$ mesh to ensure that all the columns were connected to a node of the shell element.

\section{Methodology for SSI analysis}

Aoki [6] proposed an iterative procedure based on Chamecki [5] for the SSI analysis. This methodology analysed the separate superstructure of the foundation, searching for a final balance configuration through the displacement compatibility of the superstructure/foundation.

Initially, the support loads considering the rigid base hypothesis are calculated. These loads are used to calculate the shallow foundations. The shallow foundation are considered rigid elements and a linear pressure diagram is allowed at the base/ soil contact.

The Mindlin [17] equations calculate the strain and stress in the soil points caused by a normal force. These equations consider the soil as an elastic isotropic and semi-infinite solid. Figure 5 presents the variables involved in this problem. The displacements of the shallow foundations are calculated by Eq. (1).

$r_{z}=\frac{P(1+v)}{8 \pi E(1-v)}\left[\begin{array}{c}\frac{3-4 v}{R_{1}}+\frac{8(1-v)^{2}-(3-4 v)}{R_{2}}+ \\ \frac{(z-c)^{2}}{R_{1}^{3}}+\frac{(3-4 v)(z+c)^{2}-2 c z}{R_{2}^{3}}+\frac{6 c z(z+c)^{2}}{R_{2}^{5}}\end{array}\right]$

Where $P$ is the normal force, $c$ is the depth of applying the normal force, $v$ is the PoSSlon's ratio, $B(x, y, z)$ is the point where the displacements are determined, $z$ is the depth of the $B(x, y, z)$ point and $E$ is the Young's modulus. $R_{1}$ and $R_{2}$ are calculated by the geometric properties.

In order to determine the displacements, the base of the loaded footing in subareas was discretized in which the occurrence of a

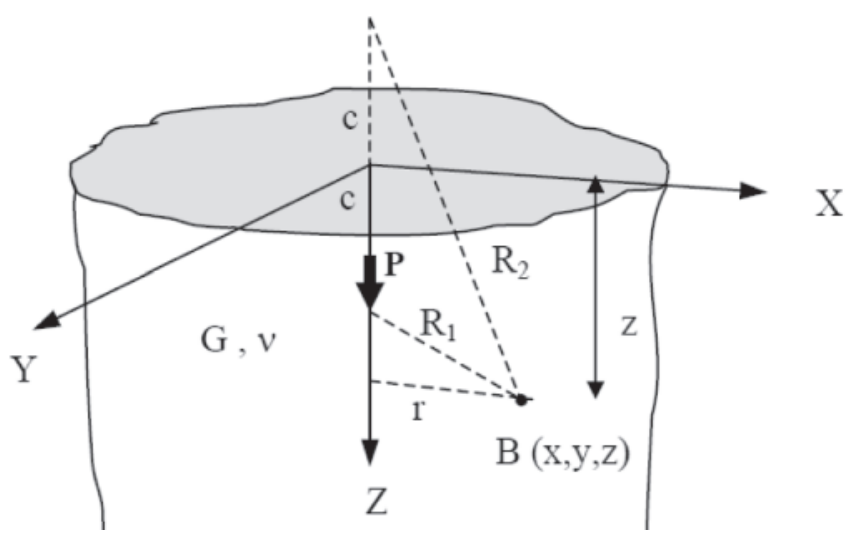

Figure 5

Semi-infinite elastic medium (Source: Mindlin, 1936) 


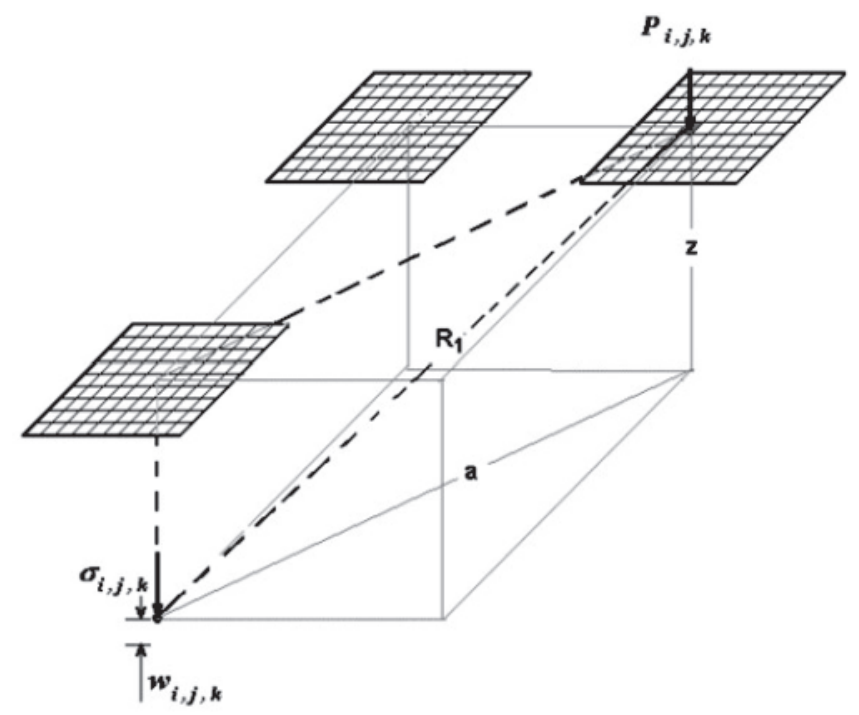

Figure 6

SSI model (Source: Reis, 2000)

concentrated load can be considered. In order to consider the group effect, the settlements are added due to the loads of all the footings in the building, according to Figure 6.

The total settlement $\delta$ of footing $\mathrm{k}$ is calculated in the geometric centre of its base by Eq. (2). The rotations in the footings were determined directly by the settlements obtained at their ends, according to Figure 7 . The stratification of the soil mass is considered using Steinbrenner's technique [18].

$\delta_{k}=\sum_{k=1}^{n^{\circ} \text { of footings }} \sum_{i=1}^{n_{1}} \sum_{j=1}^{n_{2}} r_{z_{i j k}}$

After determining the vertical settlements and the footing rotations,

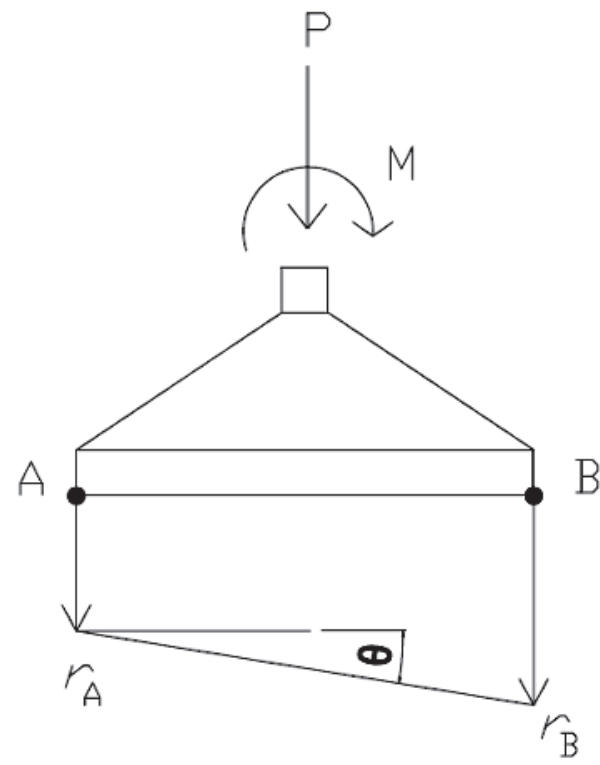

Figure 7

Determination of rotation in the shallow foundation the spring coefficients are determined by dividing the reactions of each support by the corresponding displacements. The calculated spring coefficients are imposed on the superstructure supports. Then the superstructure is recalculated and the new support reactions are determined. The whole procedure is repeated until the values of the reactions converge or the settlements are obtained between two consecutive iterations within a desired tolerance. More details about the methodology adopted can be found in Santos [10]. In this paper, the convergence criterion presented in Eq. (3) was applied, with tolerance $\xi=10^{-3}$.

$\sum_{k=1}^{n^{\mathrm{o}} \text { of footings }} \frac{\left\|P_{k}-P_{k}^{*}\right\|^{2}}{\left\|P_{k}\right\|^{2}} \leq \xi$

Where $P_{k}$ is the axial force of footing $k$ in the current iteration, $P_{k}{ }^{*}$ is the axial force of footing $k$ in the previous iteration and $\xi$ is the tolerance.

A computational routine was developed in MATLAB v7.10.0. to automate this procedure.

\section{Building description}

The evaluated building is the same one adopted in Braguim's study [2] and is an adaptation of the Condomínio das Árbores building, built in the city of São Bernado do Campo, Brazil designed by the company OSMB Engenheiros Associados Ltda. The adapted building has ten floors, wall thicknesses of $0.12 \mathrm{~m}$, slab thicknesses of $0.10 \mathrm{~m}$ and ceiling of $2.80 \mathrm{~m}$.

The adaptations aimed to simplify the computational modelling and basically consisted of considering all floors equal to the type and modifying all measurements for multiples of $0.4 \mathrm{~m}$. The layout and names of the walls are shown in Figure 8. The abbreviations $\mathrm{PH}$ and PV were used for the horizontal and vertical walls, respectively. The wall lengths are shown in Table 1.

Reinforced concrete was considered as isotropic material with the

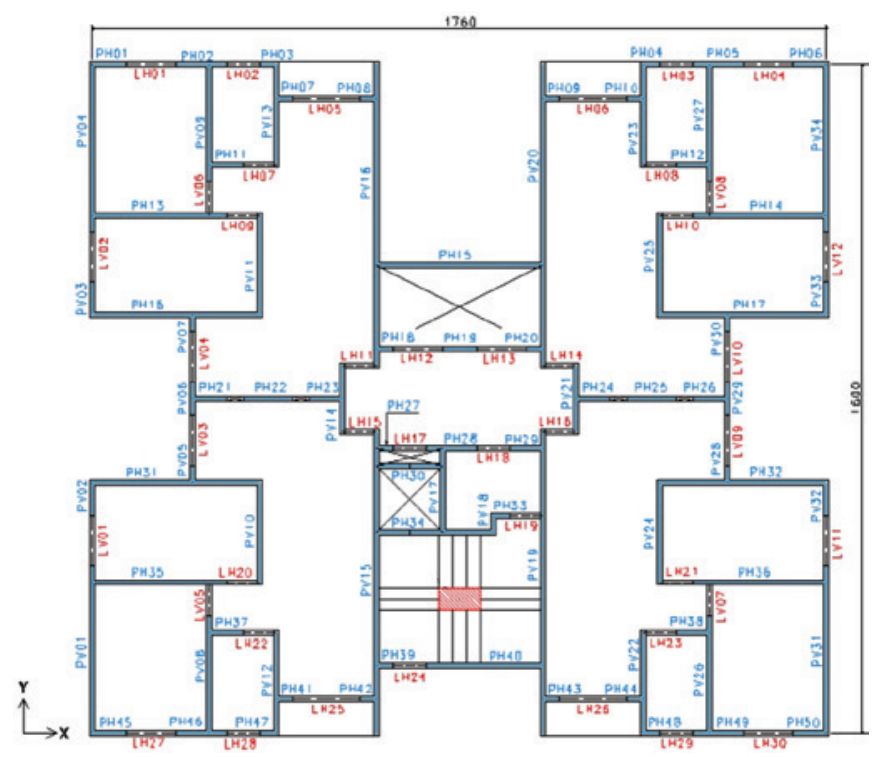

Figure 8

Floor plan of the building (Source: Braguim, 2013) 
Table 1

Length of walls

\begin{tabular}{|c|c|}
\hline Wall & Length (m) \\
\hline PH03, PH04, PH07, PH08, PH09, PH10, PH18, PH20, PH27, PH33, PH39, PH41, & 0.40 \\
PH42, PH43, PH44, PH47, PH48, PV05, PV07, PV18, PV28 and PV30 & 0.80 \\
\hline $\begin{array}{c}\text { PH01, PH06, PH11, PH12, PH19, PH21, PH23, PH24, PH26, PH29, PH37, } \\
\text { PH38, PH45, PH50, PV02, PV03, PV06, PV29 PV32 and PV33 }\end{array}$ & 1.20 \\
\hline PH02, PH05, PH22, PH25, PH28 PH46 and PH49 & 2.60 \\
\hline PH30, PV14 and PV21 & 2.40 \\
\hline PV17 & 2.80 \\
\hline PV10, PV11, PV12, PV13, PV22, PV23, PV24 and PV25 & 3.20 \\
\hline PH34, PH40, PV08, PV09, PV26 and PV27 & 4.00 \\
\hline PH13, PH14, PH35 and PH36 & 7.2 \\
\hline PH15, PH16, PH17, PH31, PH32, PV01, PV04, PV31 and PV35 \\
\hline
\end{tabular}

following mechanical properties: compression strength of 25MPa, secant modulus of elasticity of 24GPa, PoSSlon coefficient of 0.2 and specific weight of $25 \mathrm{kN} / \mathrm{m}^{3}$. In the analysis, only vertical loads were considered: dead load (sum of the weight of the structure with the slab coating loads) and live loads (overhead of residential building slabs according to NBR 6120: 1980 [20]). The stairs were simplified by considering a slab with a thickness of $0.12 \mathrm{~m}$. The load distribution of the slabs on the walls was done adopting the yield line theory, using the values presented in Table 2.

A ground beam was considered under the building with cross sec-
Table 2

Slab loads

\begin{tabular}{|c|c|c|c|}
\hline $\begin{array}{c}\text { Dead load for } \\
\mathrm{h}=10 \mathrm{~cm}\end{array}$ & $\begin{array}{c}\text { Dead load for } \\
\mathrm{h}=12 \mathrm{~cm}\end{array}$ & $\begin{array}{c}\text { Live load for } \\
\mathrm{h}=10 \mathrm{~cm}\end{array}$ & $\begin{array}{c}\text { Live load for } \\
\mathrm{h}=12 \mathrm{~cm}\end{array}$ \\
\hline $3.5 \mathrm{kN} / \mathrm{m}^{2}$ & $4.0 \mathrm{kN} / \mathrm{m}^{2}$ & $1.5 \mathrm{kN} / \mathrm{m}^{2}$ & $2.5 \mathrm{kN} / \mathrm{m}^{2}$ \\
\hline
\end{tabular}

tion dimensions of $0.2 \mathrm{~m} \times 0.5 \mathrm{~m}$. In the computational model, the ground beam was discretized by beam elements. A total of 47 shallow foundation were used at $1.5 \mathrm{~m}$ depth, according to Figure 9. The foundation design was defined after considering the

Table 3

Characteristics of the footings

\begin{tabular}{|c|c|c|c|c|c|c|c|c|c|}
\hline Found. & SPT & A $(\mathbf{m})$ & $\mathbf{B}(\mathbf{m})$ & $\mathbf{H}(\mathbf{m})$ & Found. & SPT & A $(\mathbf{m})$ & B $(\mathbf{m})$ & H $(\mathbf{m})$ \\
\hline F01 & S1 & 2.0 & 2.0 & 0.8 & F24 & S2 & 2.3 & 1.8 & 0.8 \\
\hline F02 & S1 & 1.8 & 2.5 & 0.9 & F25 & S3 & 1.9 & 1.5 & 0.6 \\
\hline F03 & S2 & 1.8 & 2.5 & 0.9 & F26 & S2 & 1.9 & 1.5 & 0.6 \\
\hline F04 & S2 & 2.0 & 2.0 & 0.8 & F27 & S1 & 2.0 & 2.0 & 0.8 \\
\hline F05 & S1 & 2.2 & 2.2 & 0.8 & F28 & S3 & 2.0 & 2.0 & 0.8 \\
\hline F06 & S2 & 2.2 & 2.2 & 0.8 & F29 & S2 & 2.0 & 2.0 & 0.8 \\
\hline F07 & S1 & 1.2 & 2.7 & 0.9 & F30 & S2 & 2.0 & 2.0 & 0.8 \\
\hline F08 & S1 & 1.9 & 0.8 & 0.8 & F31 & S3 & 3.5 & 1.9 & 1.1 \\
\hline F09 & S2 & 1.9 & 0.8 & 0.8 & F32 & S3 & 3.5 & 1.8 & 1.1 \\
\hline F10 & S2 & 1.2 & 2.7 & 0.9 & F33 & S3 & 2.5 & 2.5 & 0.9 \\
\hline F11 & S1 & 2.5 & 2.5 & 0.9 & F34 & S3 & 1.1 & 1.5 & 0.6 \\
\hline F12 & S1 & 1.1 & 1.5 & 0.6 & F35 & S3 & 1.1 & 1.5 & 0.6 \\
\hline F13 & S2 & 1.1 & 1.5 & 0.6 & F36 & S2 & 2.5 & 2.5 & 0.9 \\
\hline F14 & S2 & 2.5 & 2.5 & 0.9 & F37 & S3 & 3.5 & 1.2 & 1.1 \\
\hline F15 & S1 & 3.0 & 2.0 & 1.0 & F38 & S3 & 1.2 & 2.7 & 0.9 \\
\hline F16 & S2 & 3.0 & 2.0 & 1.0 & F39 & S3 & 1.9 & 0.8 & 0.8 \\
\hline F17 & S1 & 2.0 & 2.0 & 0.8 & F40 & S3 & 1.9 & 0.8 & 0.8 \\
\hline F18 & S1 & 2.0 & 2.0 & 0.8 & F41 & S3 & 1.2 & 2.7 & 0.9 \\
\hline F19 & S2 & 2.0 & 2.0 & 0.8 & F42 & S3 & 2.2 & 2.2 & 0.8 \\
\hline F20 & S2 & 2.0 & 2.0 & 0.8 & F43 & S3 & 2.2 & 2.2 & 0.8 \\
\hline F21 & S1 & 1.9 & 1.5 & 0.6 & F44 & S3 & 2.0 & 2.0 & 0.8 \\
\hline F22 & S2 & 1.9 & 1.5 & 0.6 & F45 & S3 & 1.8 & 2.5 & 0.9 \\
\hline F23 & S1 & 2.3 & 1.8 & 0.8 & F46 & S3 & 1.8 & 2.5 & 0.9 \\
\hline- & - & - & - & - & F47 & S3 & 20 & 2.0 & 0.8 \\
\hline
\end{tabular}




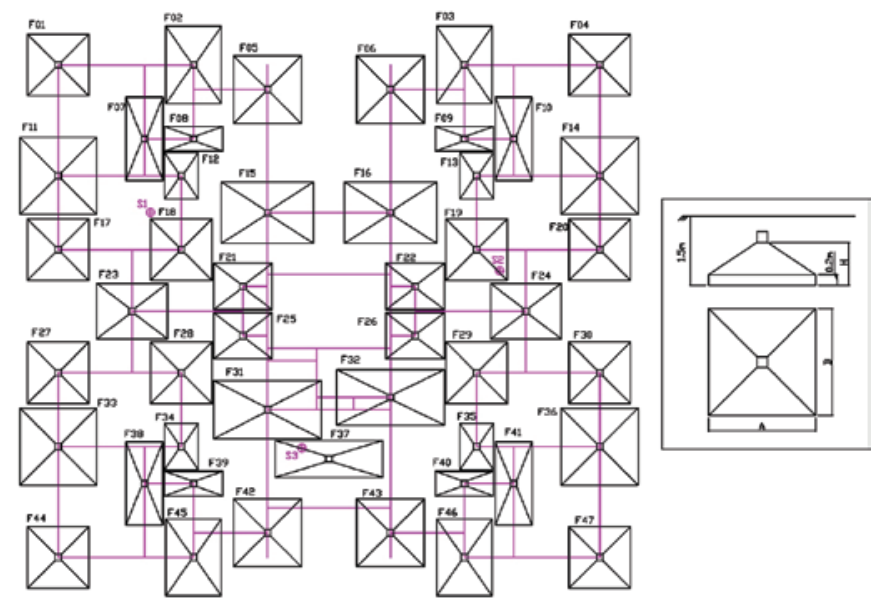

Figure 9

Foundation plan

normal loading results of the model with fixed supports, assuming the symmetry of the foundations. Table 3 shows the characteristics of the shallow foundations adopted in the design.

To characterize the soil type, the boreholes used in Santos' paper were adopted [10]. This profile has three SPT (Standard Penetration Test) boreholes, identified by S1, S2 and S3, located according to the Figure 9. Table 4 presents a summary of the Young's modulus values for each soil layer considered in the borehole. The PoSSIon coefficient was adopted at 0.30 for all layers. The Young's modulus values were estimated based on the soil parameters, as described in Santos [10].

\section{Results and discussion}

In the first series of comparisons, the effects produced in the building after considering the soil-structure interaction are presented. To do this, comparisons are made between the SHELL model with the rigid supports (SHELL RIG) and the SHELL model with the movable supports (SHELL SSI), using the methodology described in item 3. The results of the normal stress in the walls, the loads applied to the foundations and the settlements of the shallow foundations are presented. The desired convergence in the sixth iteration was obtained using the SHELL SSI model.

In the second series of comparisons, the results of the proposed simplified model (MIXED model) are presented. The results obtained in the MIXED model are compared with the reference model (SHELL model). In the simplified model analysis, the soil-structure interaction is addressed in two ways. In the first one, called the MIXED SSI model, the soil-structure interaction is considered using the methodology presented in item 3 . In the second approach, called the MIXED SIMP model, the spring coefficients are determined by the estimated settling method, which basically consists of dividing the reactions of each support by its settlement, obtained by Mindlin's equation [17]. In practice, the spring coefficient of the MIXED SIMP model is determined in the first iteration, while the spring coefficient for the MIXED SSI model is obtained after convergence of the algorithm, according to the criterion presented in Eq. (3). The MIXED SSI model produced the desired convergence in the seventh iteration. According to NBR 8681 [21], the weighting coefficient $\gamma_{f}$ can be considered as the product of two others, $\gamma_{\mathrm{f} 1}$ and $\gamma_{\mathrm{f} 3}$. The partial coefficient $\gamma_{f 1}$ considers the variability of actions and coefficient $\gamma_{f 3}$ considers the possible errors of evaluation of the effects of the actions, either by constructive problems or by deficiency of the calculation methods. Therefore, considering the weighting coefficient $\gamma_{f}=1,4$ for the normal considerations, the $\gamma_{\mathrm{f} 1}$ and $\gamma_{\mathrm{f} 3}$ coefficients can unfold in the product of two equal values, i.e., $\gamma_{\mathrm{f} 1}=\gamma_{\mathrm{f} 3}=1.18$. Thus, the variation of $18 \%$ would be considered covered by $\gamma_{\mathrm{f} 3}=1.18$.

In this paper, the differences below $5 \%$ are considered as an excellent approximation. Values between 5 and $18 \%$ are considered good or satisfactory approximation. Differences above $18 \%$ are considered bad or unacceptable.

\subsection{First series of comparisons}

Initially, the effects caused by considering the soil-structure interaction in the normal stresses of the building's walls were evaluated. The normal stresses (at the foundation level) of the building's walls are presented and compared in Table 5.

Consideration of the soil-structure interaction generated a redistribution of the stresses of the building walls, with a mean absolute deviation of $34 \%$. This redistribution of stresses is accounted for by the high rigidity of the superstructure, which limits differential settlements and sets a trend towards settlement uniformisation. Therefore, symmetrical walls with the same geometric characteristics present different normal stresses due to soil heterogeneity. Among all the walls of the building, $64 \%$ presented differences greater than $18 \%$ and out of these, approximately half had an increase of normal requests. There are marked increases in stresses, for example on $\mathrm{PH} 04, \mathrm{PH} 43, \mathrm{PH} 44$ and $\mathrm{PH} 50$ walls which increased by more than $100 \%$ and which would exceed the normalized resistance limits.

Figure 10 shows the normal force diagrams on some of the building's walls. We decided to analyse $\mathrm{PH} 01, \mathrm{PH} 02, \mathrm{PH} 03, \mathrm{PH} 13$, PH15, PV06, PV09, PV13 and PV16 walls because they had different characteristics (length, door and window openings, etc.) and

\section{Table 4}

Young's modulus values

\begin{tabular}{|c|c|c|c|}
\hline \multirow{2}{*}{$\begin{array}{c}\text { Borehole } \\
\text { (SPT) }\end{array}$} & \multicolumn{2}{|c|}{ Depth $(\mathbf{m})$} & E \\
\cline { 2 - 4 } & Start & End & (MPa) \\
\hline \multirow{4}{*}{ S1 } & 0.00 & 1.50 & 12.60 \\
\cline { 2 - 4 } & 1.50 & 3.00 & 32.40 \\
\cline { 2 - 4 } & 3.00 & 7.00 & 142.40 \\
\cline { 2 - 4 } & 7.00 & 10.00 & 292.80 \\
\hline \multirow{4}{*}{ S2 } & 0.00 & 3.00 & 11.20 \\
\cline { 2 - 4 } & 3.00 & 4.00 & 21.12 \\
\cline { 2 - 4 } & 4.00 & 6.00 & 136.40 \\
\hline \multirow{4}{*}{ S3 } & 6.00 & 10.00 & 194.70 \\
\cline { 2 - 4 } & 0.00 & 1.50 & 11.88 \\
\cline { 2 - 4 } & 1.50 & 3.00 & 28.36 \\
\cline { 2 - 4 } & 3.00 & 7.00 & 90.44 \\
\hline
\end{tabular}


are subject to different levels of loading. The percentage values in the graph indicate the differences in normal forces between the SHELL RIG and SHELL SSI models.

It can be observed that the greatest differences between the normal stress values in the building's walls occur, as expected, on the lower floors. However, in some of the building's walls, the influence of the soil-structure interaction affected the upper floors, for example in the PH03, PV13 and PV16 walls. The loads applied in the building's foundation obtained from the shell model with the fixed supports were compared with the loads obtained from the shell model on the flexible supports, presented in Table 6. Figure 11 shows a graph of the dispersion of values of the vertical load applied in the foundations. In this graph, the peripheral foundations are highlighted by vertical lines.

\section{Table 5}

Normal wall force - kN

\begin{tabular}{|c|c|c|c|c|c|c|c|}
\hline Wall & Shell RIG & Shell SSI & Differ. (\%) & Wall & Shell RIG & Shell SSI & Differ. (\%) \\
\hline $\mathrm{PHOI}$ & 199.6 & 268.9 & 35 & $\mathrm{PH} 45$ & 194.9 & 193.9 & 0 \\
\hline $\mathrm{PHO} 2$ & 23.3 & 26.2 & 12 & $\mathrm{PH} 46$ & 23.3 & 15.9 & -32 \\
\hline $\mathrm{PHO3}$ & 127.5 & 243.2 & 91 & $\mathrm{PH} 47$ & 126.5 & 191.4 & 51 \\
\hline $\mathrm{PHO4}$ & 124.4 & 268.0 & 115 & $\mathrm{PH} 48$ & 123.1 & 237.9 & 93 \\
\hline $\mathrm{PHO5}$ & 24.4 & 18.7 & -24 & PH49 & 24.7 & 35.6 & 44 \\
\hline $\mathrm{PHO6}$ & 205.1 & 283.6 & 38 & PH50 & 199.8 & 431.0 & 116 \\
\hline $\mathrm{PHO7}$ & 37.2 & 52.0 & 40 & Column & 630.0 & 630.0 & 0 \\
\hline $\mathrm{PHO8}$ & 122.8 & 209.1 & 70 & PV01 & 657.1 & 493.0 & -25 \\
\hline PH09 & 126.3 & 50.5 & -60 & PV02 & 199.6 & 194.2 & -3 \\
\hline $\mathrm{PH} 10$ & 35.0 & 52.0 & 49 & PV03 & 197.3 & 194.8 & -1 \\
\hline $\mathrm{PH} 11$ & 212.0 & 174.7 & -18 & PV04 & 658.1 & 716.4 & 9 \\
\hline $\mathrm{PH} 12$ & 208.9 & 123.4 & -41 & PV05 & 11.5 & 12.3 & 7 \\
\hline $\mathrm{PH} 13$ & 358.8 & 399.9 & 11 & PV06 & 233.6 & 227.4 & -3 \\
\hline $\mathrm{PH} 14$ & 362.8 & 257.5 & -29 & PV07 & 11.1 & 7.4 & -33 \\
\hline PH15 & 560.2 & 498.9 & -11 & PV08 & 404.1 & 300.3 & -26 \\
\hline $\mathrm{PH} 16$ & 538.6 & 625.6 & 16 & PV09 & 396.1 & 370.7 & -6 \\
\hline $\mathrm{PH} 17$ & 539.9 & 469.1 & -13 & PV10 & 505.0 & 369.8 & -27 \\
\hline $\mathrm{PH} 18$ & -14.9 & -17.7 & 19 & PV11 & 508.0 & 548.1 & 8 \\
\hline PH19 & 24.0 & 18.0 & -25 & PV12 & 479.7 & 458.6 & -4 \\
\hline $\mathrm{PH} 20$ & -15.7 & -6.5 & -59 & PV13 & 469.6 & 575.1 & 22 \\
\hline $\mathrm{PH} 21$ & 73.0 & 129.0 & 77 & PV14 & 495.3 & 594.4 & 20 \\
\hline $\mathrm{PH} 22$ & 214.9 & 214.9 & 0 & PV15 & 1464.1 & 1131.7 & -23 \\
\hline $\mathrm{PH} 23$ & -53.2 & -36.5 & -31 & PV16 & 1069.7 & 1689.0 & 58 \\
\hline $\mathrm{PH} 24$ & -49.7 & -76.7 & 54 & PV17 & 21.6 & 13.7 & -37 \\
\hline $\mathrm{PH} 25$ & 214.9 & 214.9 & 0 & PV18 & 19.0 & 21.4 & 13 \\
\hline $\mathrm{PH} 26$ & 68.0 & 129.0 & 90 & PV19 & 1383.2 & 1320.0 & -5 \\
\hline $\mathrm{PH} 27$ & 20.3 & 25.0 & 23 & PV20 & 1093.4 & 777.8 & -29 \\
\hline $\mathrm{PH} 28$ & 24.0 & 28.5 & 19 & PV21 & 490.7 & 391.0 & -20 \\
\hline $\mathrm{PH} 29$ & 12.9 & 3.4 & -74 & PV22 & 471.2 & 580.6 & 23 \\
\hline PH30 & 38.1 & 28.2 & -26 & PV23 & 460.4 & 364.7 & -21 \\
\hline PH31 & 545.6 & 604.1 & 11 & PV24 & 487.4 & 445.8 & -9 \\
\hline PH32 & 547.1 & 401.0 & -27 & PV25 & 490.9 & 337.5 & -31 \\
\hline PH33 & 84.9 & 106.0 & 25 & PV26 & 406.3 & 503.5 & 24 \\
\hline PH34 & 412.7 & 310.5 & -25 & PV27 & 397.4 & 271.7 & -32 \\
\hline PH35 & 362.1 & 354.1 & -2 & PV28 & 11.5 & 3.4 & -70 \\
\hline PH36 & 366.1 & 259.0 & -29 & PV29 & 235.2 & 218.7 & -7 \\
\hline PH37 & 216.7 & 134.7 & -38 & PV30 & 11.0 & 7.9 & -28 \\
\hline PH38 & 213.4 & 217.8 & 2 & PV31 & 679.4 & 973.0 & 43 \\
\hline PH39 & 33.0 & 27.9 & -15 & PV32 & 209.9 & 233.8 & 11 \\
\hline $\mathrm{PH} 40$ & 110.3 & 97.8 & -11 & PV33 & 207.7 & 237.3 & 14 \\
\hline $\mathrm{PH} 41$ & 35.4 & 33.6 & -5 & PV34 & 680.1 & 713.0 & 5 \\
\hline PH42 & 170.4 & 126.5 & -26 & SUM & 24509.3 & 24960.8 & - \\
\hline $\mathrm{PH} 43$ & 177.4 & 425.0 & 140 & Average & - & - & 34 \\
\hline $\mathrm{PH} 44$ & 32.8 & 154.2 & 371 & - & - & - & - \\
\hline
\end{tabular}


PH01

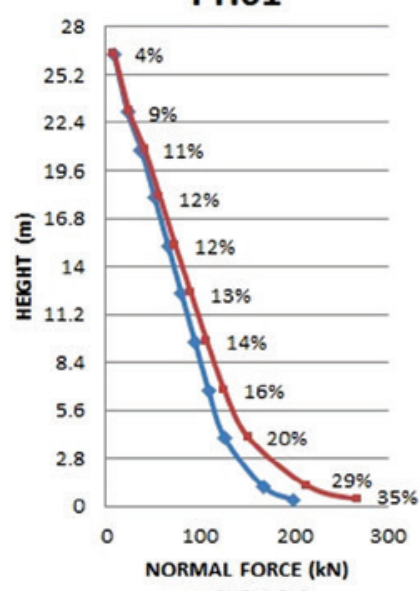

$\because$ SHELL RIG

- SHELLSSI

PH13

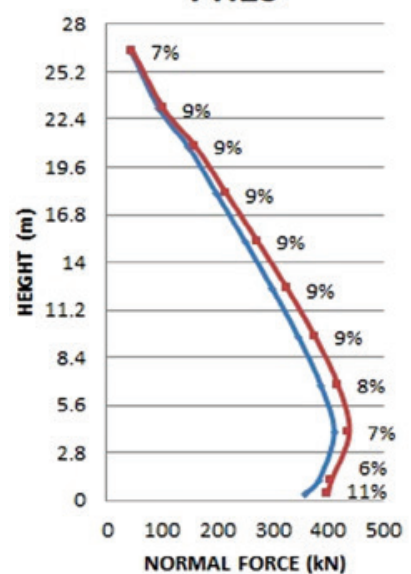

ORMAL FORCE ( $\mathrm{kN})$

PV09

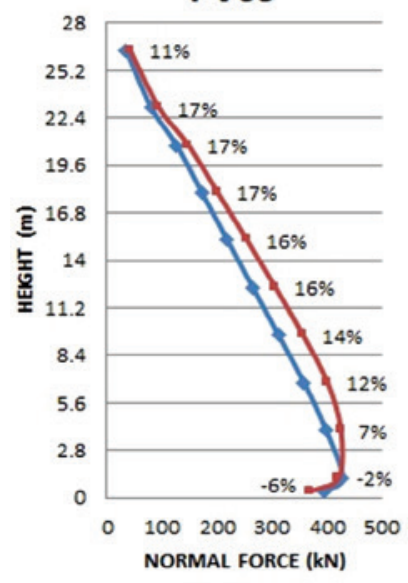

$\longrightarrow$ SHELL RIG

-SHELL SSI

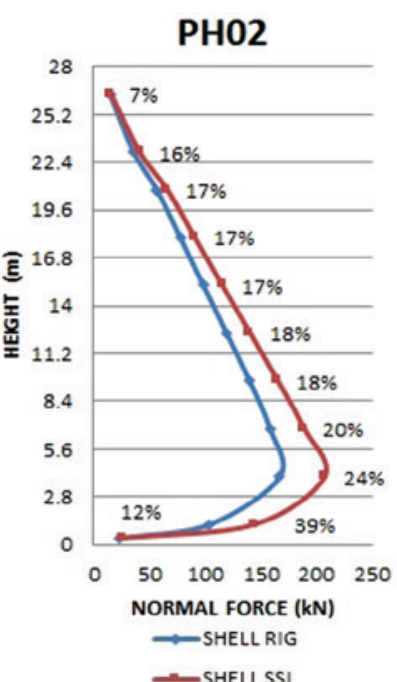

PH15

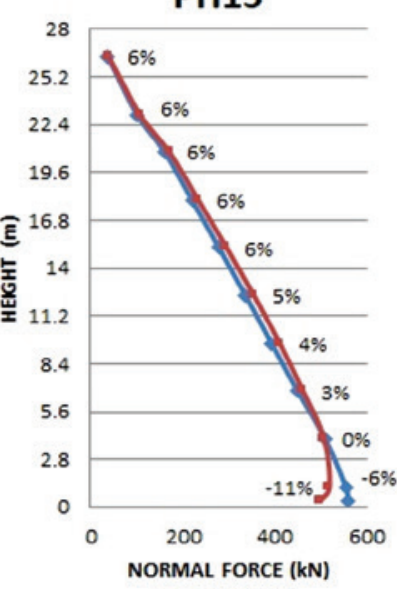

$\because$ SHELL RIG

—SHELLSSI

PV13

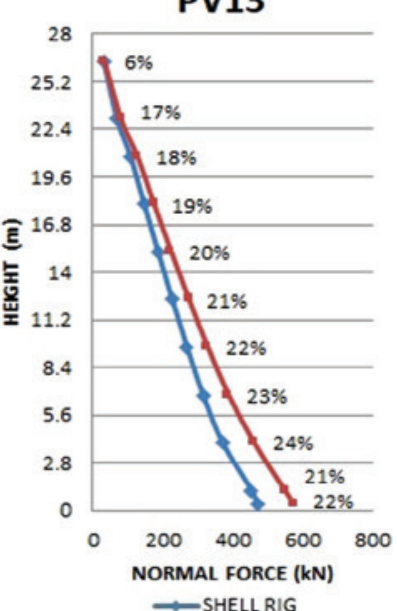

$\because$ SHELL RIG

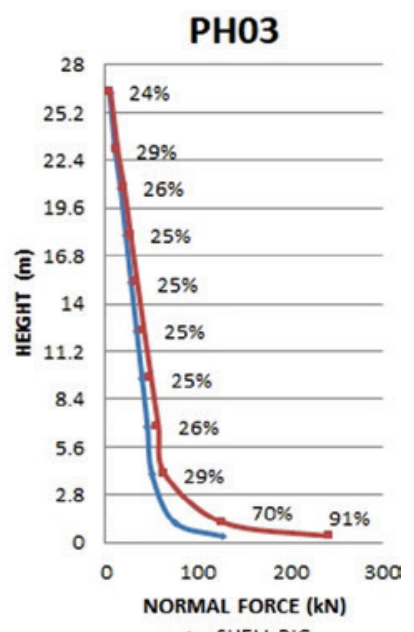

$\longrightarrow$ SHELL RIG

-SHELL SSI

PV06

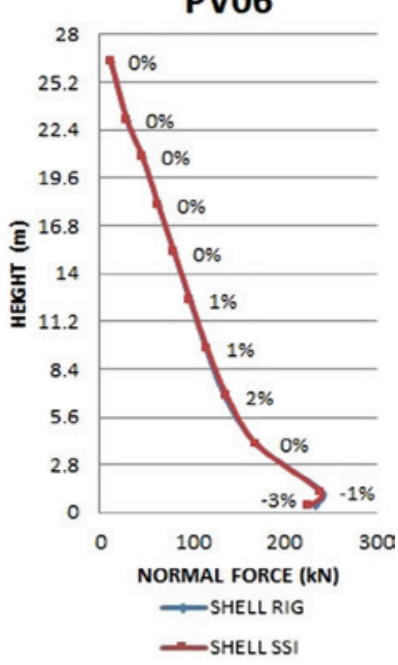

PV16

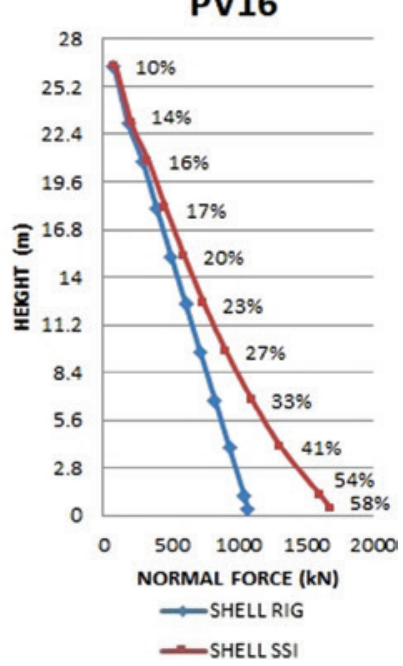

Figure 10

Normal force diagram of the buildings walls 


\section{Table 6}

Loading of the foundations - kN and kN.m

\begin{tabular}{|c|c|c|c|c|c|c|c|c|c|}
\hline \multirow{2}{*}{ Found. } & \multicolumn{3}{|c|}{$\mathrm{Nz}$} & \multicolumn{3}{|c|}{$M x$} & \multicolumn{3}{|c|}{ My } \\
\hline & Shell RIG & Shell SSI & Differ. (\%) & Shell RIG & Shell SSI & Differ. (\%) & Shell RIG & Shell SSI & Differ. (\%) \\
\hline F01 & 508.9 & 701.7 & 38 & -47.7 & -67.4 & 41 & -46.6 & -83.4 & 79 \\
\hline F02 & 521.9 & 791.6 & 52 & -45.3 & 23.1 & -151 & 49.2 & 1.5 & -97 \\
\hline F03 & 509.8 & 535.7 & 5 & -44.2 & 0.0 & -100 & -48.8 & -12.9 & -74 \\
\hline F04 & 526.8 & 628.7 & 19 & -49.4 & 21.3 & -143 & 47.5 & 5.6 & -88 \\
\hline F05 & 582.6 & 1073.8 & 84 & -9.5 & 0.0 & -100 & 26.1 & 0.0 & -100 \\
\hline F06 & 590.7 & 470.2 & -20 & -9.8 & 0.0 & -100 & -26.7 & 8.5 & -132 \\
\hline F07 & 584.7 & 519.0 & -11 & 10.7 & 0.0 & -100 & -29.0 & 0.0 & -100 \\
\hline F08 & 290.4 & 262.6 & -10 & 42.6 & 0.0 & -100 & 17.6 & 0.0 & -100 \\
\hline F09 & 283.0 & 179.3 & -37 & 41.7 & 0.0 & -100 & -16.9 & 0.0 & -100 \\
\hline $\mathrm{F} 10$ & 583.6 & 375.2 & -36 & 11.8 & 0.0 & -100 & 27.8 & 0.0 & -100 \\
\hline $\mathrm{F} 11$ & 747.6 & 805.0 & 8 & 12.6 & 0.0 & -100 & -51.8 & -138.9 & 168 \\
\hline $\mathrm{F} 12$ & 331.2 & 278.5 & -16 & -45.2 & 0.0 & -100 & 41.7 & 0.0 & -100 \\
\hline $\mathrm{F} 13$ & 319.3 & 184.4 & -42 & -43.8 & 0.0 & -100 & -39.6 & -1.0 & -97 \\
\hline F14 & 772.9 & 719.3 & -7 & 12.8 & 0.0 & -100 & 52.0 & 0.0 & -100 \\
\hline F15 & 872.4 & 1196.5 & 37 & -2.9 & 0.0 & -100 & -53.4 & -55.3 & 4 \\
\hline F16 & 900.2 & 505.8 & -44 & -3.1 & 0.0 & -100 & 54.1 & -15.9 & -129 \\
\hline F17 & 470.8 & 545.1 & 16 & 35.2 & -4.6 & -113 & -47.4 & -106.0 & 123 \\
\hline F18 & 541.6 & 580.2 & 7 & 44.7 & 41.4 & -7 & 50.0 & 0.0 & -100 \\
\hline F19 & 519.0 & 388.2 & -25 & 43.0 & 7.8 & -82 & -49.0 & $\begin{array}{l}-17.1 \\
\end{array}$ & -65 \\
\hline F2O & 495.1 & 501.0 & 1 & 37.0 & 0.0 & -100 & 48.7 & 0.0 & -100 \\
\hline F21 & 347.3 & 520.5 & 50 & -41.9 & -31.9 & -24 & -44.8 & -36.6 & -18 \\
\hline F22 & 346.3 & 256.5 & -26 & -41.4 & 0.0 & -100 & 44.8 & 0.0 & -100 \\
\hline F23 & 592.0 & 637.4 & 8 & 0.0 & 0.0 & 0 & -72.6 & -109.8 & 51 \\
\hline F24 & 591.7 & 440.7 & -26 & 1.0 & 7.2 & 616 & 71.7 & 1.9 & -97 \\
\hline F25 & 384.7 & 328.9 & -15 & 40.3 & 0.0 & -100 & -70.7 & -52.9 & -25 \\
\hline F26 & 359.1 & 186.8 & -48 & 40.8 & 0.0 & -100 & 55.2 & 0.0 & -100 \\
\hline F27 & 478.1 & 572.4 & 20 & -35.6 & 70.7 & -299 & -48.1 & -113.8 & 137 \\
\hline F28 & 548.3 & 406.8 & -26 & -44.8 & -9.1 & -80 & 50.6 & 0.0 & -100 \\
\hline F29 & 525.9 & 267.2 & -49 & -43.1 & 0.0 & -100 & -49.6 & 0.0 & -100 \\
\hline F30 & 503.4 & 488.0 & -3 & -37.4 & 0.0 & -100 & 49.4 & 0.0 & -100 \\
\hline F31 & 1337.1 & 887.1 & -34 & 10.3 & 0.0 & -100 & -87.0 & -111.8 & 29 \\
\hline F32 & 906.7 & 1134.7 & 25 & 0.0 & 0.0 & 0 & 69.8 & 31.9 & -54 \\
\hline F33 & 755.1 & 593.9 & -21 & -12.2 & 0.0 & -100 & -52.3 & -186.5 & 256 \\
\hline F34 & 325.4 & 194.7 & -40 & 44.6 & 0.0 & -100 & 42.2 & 0.0 & -100 \\
\hline F35 & 312.0 & 377.3 & 21 & 43.0 & 0.0 & -100 & -39.9 & -24.6 & -39 \\
\hline F36 & 782.1 & 586.8 & -25 & -12.3 & 0.0 & -100 & 52.5 & 0.0 & -100 \\
\hline F37 & 630.0 & 630.0 & 0 & 1.0 & 0.0 & -100 & -7.1 & -138.8 & 1867 \\
\hline F38 & 597.2 & 411.2 & -31 & -10.2 & 0.0 & -100 & -29.6 & 0.0 & -100 \\
\hline F39 & 301.4 & 210.0 & -30 & -43.9 & 0.0 & -100 & 17.9 & -3.4 & -119 \\
\hline F40 & 295.1 & 264.8 & -10 & -43.1 & 0.0 & -100 & -17.2 & 3.0 & -117 \\
\hline F41 & 597.7 & 718.0 & 20 & -11.2 & 17.5 & -257 & 28.4 & 0.0 & -100 \\
\hline F42 & 824.7 & 741.0 & -10 & 22.3 & 0.0 & -100 & 32.7 & 0.0 & -100 \\
\hline F43 & 857.0 & 934.7 & 9 & 25.2 & 0.0 & -100 & -34.4 & -574.5 & 1571 \\
\hline F44 & 496.9 & 542.2 & 9 & 47.1 & 81.0 & 72 & -45.6 & -74.4 & 63 \\
\hline F45 & 519.6 & 637.3 & 23 & 45.8 & -6.6 & -114 & 48.5 & 0.0 & -100 \\
\hline F46 & 505.5 & 815.4 & 61 & 44.7 & -7.5 & -117 & -48.0 & -53.6 & 12 \\
\hline F47 & 513.2 & 1159.8 & 126 & 48.8 & 133.9 & 174 & 46.3 & 34.5 & -25 \\
\hline Total & 26185.8 & 26185.8 & - & - & - & - & - & - & - \\
\hline Average & - & - & 27 & - & - & 113 & - & - & 160 \\
\hline
\end{tabular}




\section{VERTICAL LOAD OF THE BUILDING FOUNDATIONS}

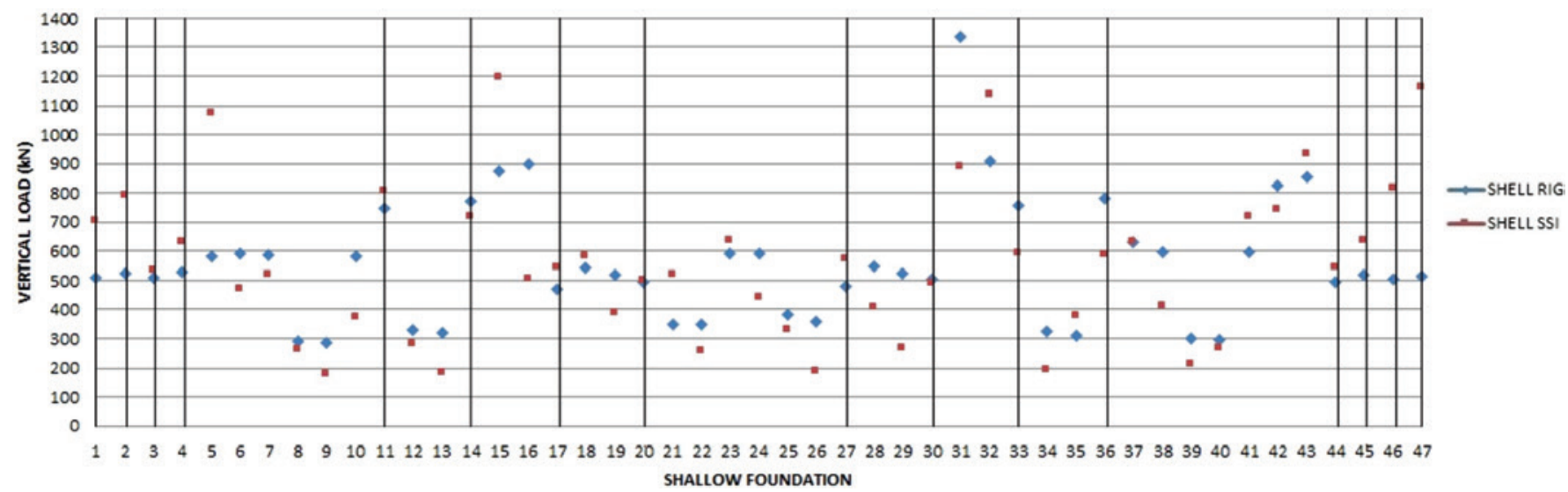

Figure 11

Scatter plot of the vertical load of the building foundations

In general, load redistribution occurred in the building's foundations with a mean absolute deviation of $27 \%$. Approximately $64 \%$ of the foundations showed differences of more than $18 \%$, highlighting the increase of $126 \%$ in the F47 footing. There was also a tendency to reduce the bending moment in both directions, where the majority of the values were cancelled.

The mechanism that governs the load redistribution in the supports is the tendency to standardize the settlements. In the analysed building, the foundations located in the region of the S2 borehole show the behaviour of yielding to the neighborhood, since this region presented the highest settlements. There is also a trend of load transfer to the peripheral foundations.

Table 7 shows the vertical displacement of the supports of the building and Table 8 presents some information about the behaviour of the

Table 7

Settlement of the building supports - $\mathrm{mm}$

\begin{tabular}{|c|c|c|c|c|c|c|c|}
\hline Found. & Shell RIG & Shell SSI & Differ. (\%) & Found. & Shell RIG & Shell SSI & Differ. (\%) \\
\hline F01 & 3.2 & 4.3 & 35 & F24 & 12.5 & 9.3 & -25 \\
\hline F02 & 3.6 & 5.4 & 47 & F25 & 6.6 & 6.0 & -9 \\
\hline $\mathrm{FO3}$ & 9.7 & 9.5 & -2 & F26 & 12.5 & 8.5 & -32 \\
\hline F04 & 9.1 & 10.7 & 18 & F27 & 3.8 & 4.1 & 9 \\
\hline F05 & 3.7 & 6.3 & 68 & F28 & 6.9 & 5.6 & -20 \\
\hline F06 & 10.2 & 8.3 & -18 & F29 & 13.2 & 8.6 & -35 \\
\hline F07 & 5.2 & 5.2 & -2 & F30 & 10.6 & 9.6 & -9 \\
\hline F08 & 5.4 & 5.5 & 1 & F31 & 8.9 & 6.6 & -26 \\
\hline F09 & 14.5 & 9.4 & -35 & F32 & 7.0 & 7.5 & 6 \\
\hline F10 & 14.4 & 9.9 & -31 & F33 & 5.1 & 4.2 & -18 \\
\hline $\mathrm{F} 11$ & 3.9 & 4.3 & 8 & F34 & 7.9 & 5.6 & -30 \\
\hline $\mathrm{F} 12$ & 5.7 & 5.5 & -4 & F35 & 7.3 & 8.1 & 10 \\
\hline $\mathrm{F} 13$ & 15.3 & 9.3 & -39 & F36 & 11.3 & 9.4 & -16 \\
\hline $\mathrm{F} 14$ & 11.2 & 10.3 & -8 & F37 & 7.0 & 6.7 & -5 \\
\hline F15 & 4.9 & 6.4 & 29 & F38 & 7.0 & 5.3 & -25 \\
\hline F16 & 13.4 & 8.0 & -40 & F39 & 7.6 & 5.7 & -25 \\
\hline F17 & 3.7 & 4.2 & 12 & F40 & 7.2 & 7.7 & 7 \\
\hline $\mathrm{F} 18$ & 4.9 & 5.4 & 9 & F41 & 6.9 & 7.9 & 15 \\
\hline F19 & 12.7 & 9.2 & -27 & F42 & 6.8 & 6.1 & -10 \\
\hline F20 & 10.4 & 10.3 & -2 & F43 & 6.8 & 7.3 & 7 \\
\hline F21 & 4.6 & 5.8 & 25 & F44 & 3.9 & 4.0 & 2 \\
\hline F22 & 11.8 & 8.2 & -30 & F45 & 5.0 & 5.3 & 6 \\
\hline F23 & 4.8 & 5.0 & 5 & $\mathrm{~F} 46$ & 4.9 & 7.0 & 43 \\
\hline- & - & - & - & F47 & 4.0 & 8.5 & 112 \\
\hline
\end{tabular}


Table 8

Supplementary information on settlements

\begin{tabular}{|c|c|c|c|}
\hline Information & Shell RIG & Shell SSI & Differ. (\%) \\
\hline $\begin{array}{c}\text { Maximum settlement } \\
\text { (mm) }\end{array}$ & 15.3 & 10.7 & -30 \\
\hline $\begin{array}{c}\text { Maximum differential } \\
\text { settlement (mm) }\end{array}$ & 12.1 & 6.7 & -44 \\
\hline $\begin{array}{c}\text { Average settlement } \\
\text { (mm) }\end{array}$ & 7.8 & 7.0 & -10 \\
\hline $\begin{array}{c}\text { Coefficient of variation } \\
\text { (\%) }\end{array}$ & 44 & 28 & -37 \\
\hline
\end{tabular}

settlements after considering the soil-structure interaction. Figures 12 and 13 present the isosettlement curves for the SHELL RIG and SHELL SSI models, respectively. To make the isosettlement curves, the centroid coordinates of each footing were considered in the $(x, y)$ plane and the settlement was adopted as the $z$ coordinate. The linear triangulation interpolation method was used to determine the multiple settlement values of $0.5 \mathrm{~mm}$, and thus generate the same value curves.

Observing the isosettlement curves of the SHELL RIG model, it can be observed that the largest settlements are in the region of the S2 borehole, where the soil is more deformable. However, when analysing the soil-structure interaction, a reduction of the settlements in this region can be observed, accounted for by the rigidity of the superstructure that limits differential settlements and redistributes the loads to the neighbouring foundations.

The results show a reduction of $44 \%$ in the maximum differential settlement and $30 \%$ in the maximum settlement. The reduction in the coefficient of variation emphasizes the tendency of settlement uniformisation caused by the consideration of the soilstructure interaction. The average settlement presented a low reduction, of the order of $10 \%$. When analysing the isosettlement curves, a clear trend of settlement uniformisation can be clearly observed.

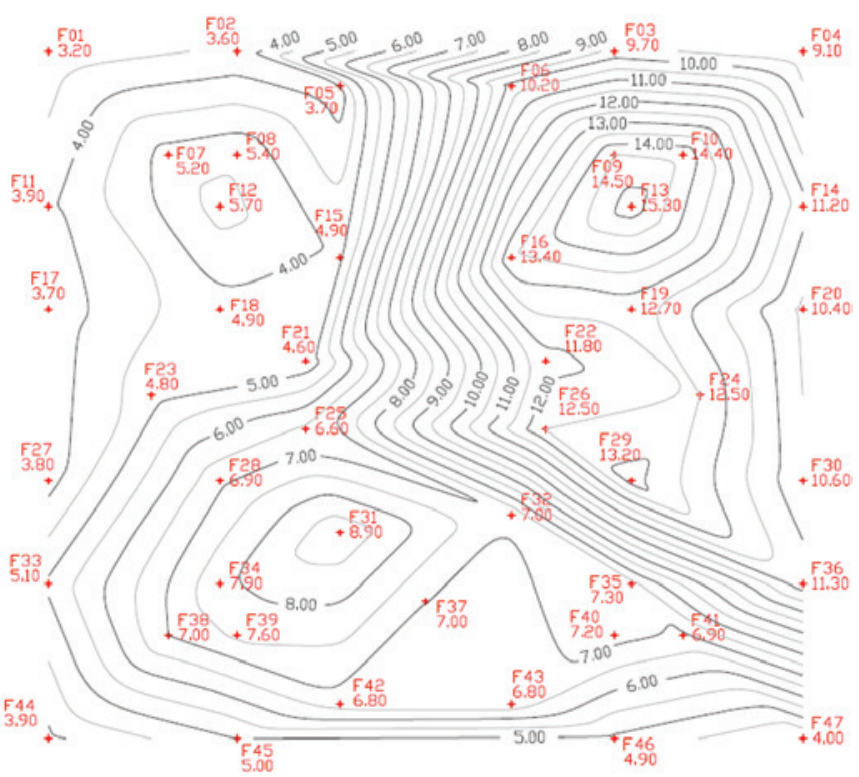

Figure 12

Isosettlement curve of the SHELL RIG model

\subsection{Second series of comparisons}

The results of the simplified models are compared and evaluated. In Table 9, the normal (foundation level) stresses of the building walls were compared. Figure 14 shows the diagrams of normal force along the walls studied.

By analysing the results of the normal force on the building's walls, it can be observed that the simplified models were able to adequately represent the load distribution between the walls. However, there is a perturbation on the second floor. This perturbation is accounted for by the concentration of force at the top of the wall (transition from the column element to the shell element). This characteristic does not interfere in the results, as in all cases the diagram, outside the perturbation region, presented good results, compared to the more refined model.

The MIXED SSI model presented a mean absolute deviation of $9 \%$, where $45 \%$ of the walls had excellent results, $44 \%$ had good results and only $12 \%$ presented results with differences above $18 \%$. The quality of the MIXED SIMP model is somewhat lower, but represents the redistribution of loads between the walls. This model presented a mean absolute deviation of $15 \%$, in which $22 \%$ of the results were optimal, $53 \%$ good and $25 \%$ bad.

Tables 10 and 11 present the comparisons of the loadings on the foundations for the MIXED SSI and MIXED SIMP models, respectively.

The simplified models presented a good approximation of the vertical reactions in the footings, with a mean absolute deviation of $4 \%$ and $9 \%$ for the MIXED SSI and MIXED SIMP models, respectively. The MIXED SSI model did not present any results outside the acceptable range, with $85 \%$ of the results in the optimal range and $15 \%$ in the good ones. The MIXED SIMP model presented $38 \%$ of the results in the optimal range, $53 \%$ in the good and only $9 \%$ in the bad one. For the moments applied there is a high divergence between the results.

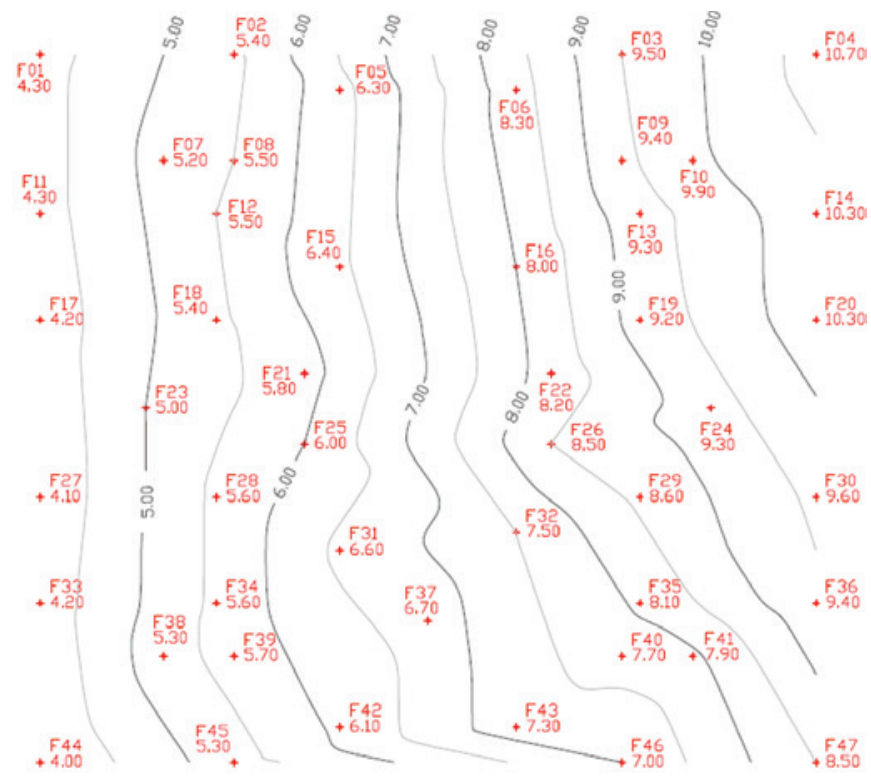

Figure 13

Isosettlement curve of the SHELL SSI model 
Table 12 shows the estimated settlements for the building foundations. Table 13 presents some additional information.

The MIXED SSI model presented excellent results, with a difference of $1 \%$ in the mean settlement and a difference of $5 \%$ for the maximum settlement and maximum differential settlement. In this model, none of the absolute settlements exceeded the $18 \%$ difference limit. The MIXED SIMP model presented a mean difference of $2 \%, 3 \%$ for the maximum and the $15 \%$ for the maximum differential. In this model only three foundations presented differences higher than the limit of $18 \%$.

\section{Conclusions}

Consideration of the soil-structure interaction caused a general

\section{Table 9}

Normal wall strength in the simplified models - kN

\begin{tabular}{|c|c|c|c|c|c|c|c|c|c|}
\hline Wall & Shell RIG & Shell SSI & Differ. (\%) & Wall & Shell RIG & Shell SSI & Differ. (\%) & Shell SSI & Differ. (\%) \\
\hline $\mathrm{PHO1}$ & 265.5 & -1 & 276.1 & 3 & $\mathrm{PH} 45$ & 222.0 & 14 & 194.4 & 0 \\
\hline $\mathrm{PHO} 2$ & 28.0 & 7 & 27.3 & 4 & $\mathrm{PH} 46$ & 17.3 & 9 & 17.8 & 12 \\
\hline $\mathrm{PHO3}$ & 240.3 & -1 & 329.0 & 35 & $\mathrm{PH} 47$ & 211.7 & 11 & 218.2 & 14 \\
\hline $\mathrm{PHO4}$ & 260.4 & -3 & 180.7 & -33 & $\mathrm{PH} 48$ & 230.1 & -3 & 254.0 & 7 \\
\hline PH05 & 20.0 & 7 & 19.4 & 4 & $\mathrm{PH} 49$ & 37.0 & 4 & 32.3 & -9 \\
\hline $\mathrm{PHO6}$ & 282.0 & -1 & 257.2 & -9 & PH50 & 445.2 & 3 & 304.2 & -29 \\
\hline $\mathrm{PHO7}$ & 60.0 & 15 & 46.8 & -10 & Column & 630.0 & 0 & 630.0 & 0 \\
\hline $\mathrm{PH} 08$ & 197.4 & -6 & 185.9 & -11 & PV01 & 542.5 & 10 & 650.0 & 32 \\
\hline PH09 & 45.7 & -9 & 54.5 & 8 & PV02 & 223.7 & 15 & 159.0 & -18 \\
\hline $\mathrm{PH} 10$ & 63.0 & 21 & 71.5 & 37 & PV03 & 199.5 & 2 & 160.0 & -18 \\
\hline $\mathrm{PH} 11$ & 171.9 & -2 & 166.4 & -5 & PV04 & 703.1 & -2 & 249.6 & -65 \\
\hline $\mathrm{PH} 12$ & 132.4 & 7 & 138.2 & 12 & PV05 & 14.8 & 20 & 16.1 & 31 \\
\hline $\mathrm{PH} 13$ & 362.8 & -9 & 523.0 & 31 & PV06 & 234.8 & 3 & 216.7 & -5 \\
\hline $\mathrm{PH} 14$ & 251.4 & -2 & 258.1 & 0 & PV07 & 6.0 & -19 & 5.0 & -33 \\
\hline $\mathrm{PH} 15$ & 509.7 & 2 & 501.9 & 1 & PV08 & 315.2 & 5 & 353.3 & 18 \\
\hline $\mathrm{PH} 16$ & 584.8 & -7 & 810.0 & 29 & PV09 & 357.0 & -4 & 418.6 & 13 \\
\hline $\mathrm{PH} 17$ & 477.9 & 2 & 500.2 & 7 & PV10 & 378.7 & 2 & 410.2 & 11 \\
\hline $\mathrm{PH} 18$ & -26.0 & 47 & -23.0 & 30 & PV11 & 538.6 & -2 & 537.4 & -2 \\
\hline $\mathrm{PH} 19$ & 26.0 & 44 & 27.6 & 53 & PV12 & 473.3 & 3 & 414.1 & -10 \\
\hline $\mathrm{PH} 2 \mathrm{O}$ & -9.0 & 39 & -7.0 & 8 & PV13 & 565.8 & -2 & 530.0 & -8 \\
\hline $\mathrm{PH} 21$ & 135.4 & 5 & 149.7 & 16 & PV14 & 569.9 & -4 & 535.8 & -10 \\
\hline $\mathrm{PH} 22$ & 214.9 & 0 & 214.9 & 0 & PV15 & 1237.7 & 9 & 1327.7 & 17 \\
\hline $\mathrm{PH} 23$ & -30.0 & -18 & -29.0 & -21 & PV16 & 1601.4 & -5 & 1531.3 & -9 \\
\hline $\mathrm{PH} 24$ & -73.6 & -4 & -68.9 & -10 & PV17 & 13.5 & -1 & 14.7 & 8 \\
\hline $\mathrm{PH} 25$ & 214.9 & 0 & 214.9 & 0 & PV18 & 21.0 & -2 & 17.2 & -20 \\
\hline $\mathrm{PH} 26$ & 111.0 & -14 & 120.0 & -7 & PV19 & 1510.0 & 14 & 1440.5 & 9 \\
\hline $\mathrm{PH} 27$ & 28.4 & 14 & 27.8 & 11 & PV20 & 732.2 & -6 & 823.1 & 6 \\
\hline $\mathrm{PH} 28$ & 32.4 & 14 & 25.8 & -10 & PV21 & 449.8 & 15 & 470.8 & 20 \\
\hline $\mathrm{PH} 29$ & 4.0 & 19 & 5.0 & 48 & PV22 & 560.0 & -4 & 568.6 & -2 \\
\hline PH30 & 31.1 & 10 & 32.8 & 16 & PV23 & 368.5 & 1 & 358.6 & -2 \\
\hline PH31 & 550.5 & -9 & 887.0 & 47 & PV24 & 468.9 & 5 & 449.6 & 1 \\
\hline PH32 & 386.6 & -4 & 438.8 & 9 & PV25 & 368.3 & 9 & 356.5 & 6 \\
\hline PH33 & 108.0 & 2 & 91.4 & -14 & PV26 & 483.4 & -4 & 473.7 & -6 \\
\hline PH34 & 339.4 & 9 & 347.9 & 12 & PV27 & 291.3 & 7 & 317.0 & 17 \\
\hline PH35 & 303.6 & -14 & 236.0 & -33 & PV28 & 3.0 & -13 & 3.0 & -13 \\
\hline PH36 & 233.8 & -10 & 273.3 & 6 & PV29 & 250.0 & 14 & 224.0 & 2 \\
\hline PH37 & 145.0 & 8 & 145.2 & 8 & PV30 & 8.4 & 6 & 9.4 & 19 \\
\hline PH38 & 204.8 & -6 & 198.4 & -9 & PV31 & 912.0 & -6 & 1001.7 & 3 \\
\hline PH39 & 28.4 & 2 & 27.1 & -3 & PV32 & 245.1 & 5 & 213.1 & -9 \\
\hline $\mathrm{PH} 40$ & 90.6 & -7 & 81.4 & -17 & PV33 & 256.2 & 8 & 207.8 & -12 \\
\hline $\mathrm{PH} 41$ & 43.4 & 29 & 27.7 & -17 & PV34 & 804.0 & 13 & 786.7 & 10 \\
\hline $\mathrm{PH} 42$ & 123.1 & -3 & 124.7 & -1 & SUM & 25059.1 & - & 25179.1 & - \\
\hline $\mathrm{PH} 43$ & 285.0 & -33 & 289.6 & -32 & Average & - & 9 & - & 15 \\
\hline $\mathrm{PH} 44$ & 103.0 & -33 & 72.0 & -53 & - & - & - & - & - \\
\hline
\end{tabular}



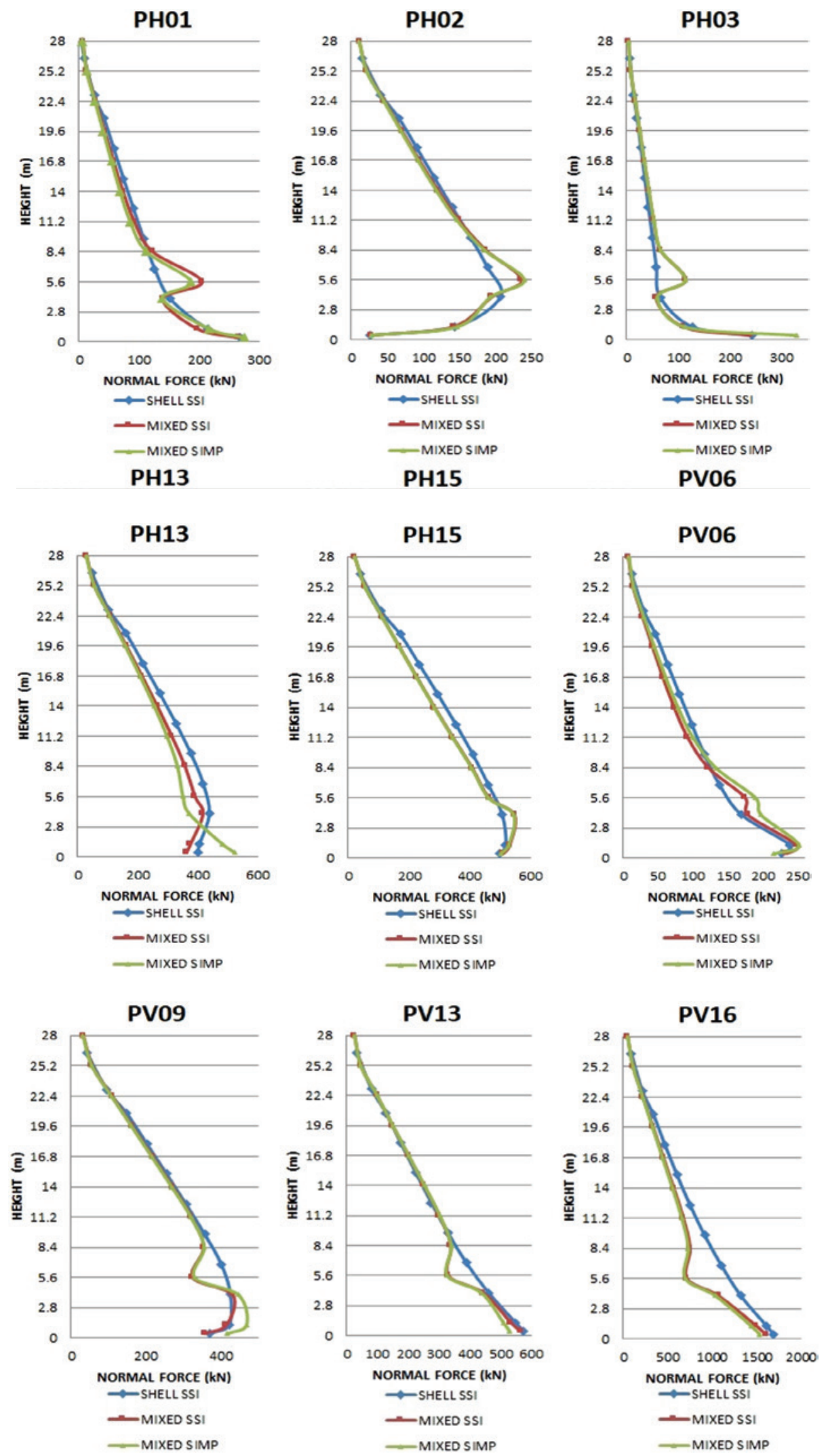

Figure 14

Normal force diagram of the walls of the simplified models 
Table 10

Loading on the foundations of the mixed model SSI - kN and kN.m

\begin{tabular}{|c|c|c|c|c|c|c|}
\hline \multirow{2}{*}{ Found. } & \multicolumn{2}{|c|}{$\mathrm{Nz}$} & \multicolumn{2}{|c|}{ Mx } & \multicolumn{2}{|c|}{ My } \\
\hline & Mixed SSI & Differ. (\%) & Mixed SSI & Differ. (\%) & Mixed SSI & Differ. (\%) \\
\hline F01 & 682.2 & -3 & -68.6 & 2 & -84.1 & 1 \\
\hline F02 & 768.3 & -3 & -24.6 & -206 & 2.9 & 98 \\
\hline F03 & 570.8 & 7 & 0.0 & 0 & -16.0 & 24 \\
\hline F04 & 657.2 & 5 & -1.4 & -106 & -71.0 & -1359 \\
\hline F05 & 1032.6 & -4 & 0.0 & 0 & 0.0 & 0 \\
\hline F06 & 468.1 & 0 & 0.0 & 0 & -9.6 & -213 \\
\hline F07 & 502.1 & -3 & 0.0 & 0 & 0.0 & 0 \\
\hline F08 & 248.5 & -5 & 0.0 & 0 & 0.0 & 0 \\
\hline F09 & 190.0 & 6 & 0.0 & 0 & 0.0 & 0 \\
\hline F10 & 399.1 & 6 & 0.0 & 0 & 0.0 & 0 \\
\hline F11 & 771.7 & -4 & 0.0 & 0 & -110.8 & -20 \\
\hline $\mathrm{F} 12$ & 273.3 & -2 & 0.0 & 0 & 0.0 & 0 \\
\hline F13 & 191.2 & 4 & 0.0 & 0 & 0.0 & -100 \\
\hline F14 & 750.6 & 4 & 0.0 & 0 & 0.0 & 0 \\
\hline F15 & 1164.9 & -3 & 0.0 & 0 & -61.3 & 11 \\
\hline F16 & 499.3 & -1 & 0.0 & 0 & 8.7 & -154 \\
\hline F17 & 525.1 & -4 & 10.5 & -327 & -86.8 & -18 \\
\hline F18 & 561.8 & -3 & 42.0 & 1 & 0.0 & 0 \\
\hline F19 & 410.9 & 6 & 16.9 & 118 & -10.9 & -37 \\
\hline F2O & 524.2 & 5 & 0.0 & 0 & 0.0 & 0 \\
\hline F21 & 515.9 & -1 & -38.8 & 22 & -30.4 & -17 \\
\hline F22 & 272.9 & 6 & 0.0 & 0 & 0.0 & 0 \\
\hline F23 & 645.4 & 1 & 0.0 & 0 & -115.1 & 5 \\
\hline F24 & 454.8 & 3 & 16.5 & 130 & -19.1 & -1104 \\
\hline F25 & 325.2 & -1 & 0.0 & -100 & -72.9 & 38 \\
\hline F26 & 196.0 & 5 & 0.0 & 0 & 0.0 & 0 \\
\hline F27 & 595.2 & 4 & -39.8 & -156 & -96.7 & -15 \\
\hline F28 & 418.1 & 3 & -11.9 & 31 & 0.0 & 0 \\
\hline F29 & 253.5 & -5 & 0.0 & 0 & 0.0 & 0 \\
\hline F30 & 490.6 & 1 & 0.0 & 0 & 0.0 & 0 \\
\hline F31 & 929.9 & 5 & 0.0 & 0 & -119.1 & 7 \\
\hline F32 & 1175.0 & 4 & 0.0 & 0 & 47.0 & 47 \\
\hline F33 & 610.0 & 3 & 0.0 & 0 & -98.6 & -47 \\
\hline F34 & 195.9 & 1 & 0.0 & 0 & 0.0 & 0 \\
\hline F35 & 367.4 & -3 & 0.0 & 0 & 10.5 & -143 \\
\hline F36 & 581.7 & -1 & 0.0 & 0 & 0.0 & 0 \\
\hline F37 & 630.0 & 0 & 0.0 & 0 & -136.7 & -1 \\
\hline F38 & 428.6 & 4 & 0.0 & 0 & 0.0 & 0 \\
\hline F39 & 219.5 & 5 & 0.0 & 0 & 1.2 & -136 \\
\hline F40 & 240.6 & -9 & 0.0 & 0 & 2.1 & -31 \\
\hline F41 & 691.9 & -4 & 3.1 & -82 & 0.0 & 0 \\
\hline F42 & 771.4 & 4 & 0.0 & 0 & 0.0 & 0 \\
\hline F43 & 904.7 & -3 & 0.0 & 0 & -30.0 & -95 \\
\hline F44 & 548.7 & 1 & 49.7 & -39 & -83.2 & 12 \\
\hline F45 & 659.2 & 3 & 9.7 & -246 & 0.0 & 0 \\
\hline F46 & 733.2 & -10 & 8.1 & -208 & -25.1 & -53 \\
\hline F47 & 1138.8 & -2 & 112.2 & -16 & 99.9 & 189 \\
\hline Total & 26185.8 & - & - & - & - & - \\
\hline Average & - & 4 & - & 38 & - & 85 \\
\hline
\end{tabular}


Table 11

Loading on the foundations mixed model SIMP-kN and kN.m

\begin{tabular}{|c|c|c|c|c|c|c|}
\hline \multirow{2}{*}{ Found. } & \multicolumn{2}{|c|}{$\mathrm{Nz}$} & \multicolumn{2}{|c|}{ Mx } & \multicolumn{2}{|c|}{ My } \\
\hline & Mixed SIMP & Differ. (\%) & Mixed SIMP & Differ. (\%) & Mixed SIMP & Differ. (\%) \\
\hline F01 & 708.7 & 1 & -83.4 & 24 & -91.7 & 10 \\
\hline F02 & 747.1 & -6 & 199.7 & 763 & 41.6 & 2747 \\
\hline F03 & 547.7 & 2 & 0.0 & 0 & -25.5 & 98 \\
\hline F04 & 655.8 & 4 & -61.9 & -391 & 20.8 & 268 \\
\hline F05 & 963.4 & -10 & 0.0 & 0 & 0.0 & 0 \\
\hline F06 & 483.3 & 3 & 0.0 & 0 & 29.9 & 252 \\
\hline F07 & 563.5 & 9 & 0.0 & 0 & 0.0 & 0 \\
\hline F08 & 288.4 & 10 & 0.0 & 0 & 0.0 & 0 \\
\hline F09 & 198.6 & 11 & 0.0 & 0 & 0.0 & 0 \\
\hline F10 & 432.9 & 15 & 0.0 & 0 & 0.0 & 0 \\
\hline $\mathrm{Fll}$ & 895.7 & 11 & 0.0 & 0 & -704.0 & 407 \\
\hline $\mathrm{F} 12$ & 302.5 & 9 & 0.0 & 0 & 0.0 & 0 \\
\hline $\mathrm{F} 13$ & 204.9 & 11 & 0.0 & 0 & -17.2 & 1565 \\
\hline F14 & 747.6 & 4 & 0.0 & 0 & 0.0 & 0 \\
\hline F15 & 1132.0 & -5 & 0.0 & 0 & -62.3 & 13 \\
\hline F16 & 541.2 & 7 & 0.0 & 0 & -5.2 & -67 \\
\hline $\mathrm{F} 17$ & 393.9 & -28 & $\begin{array}{l}-194.0 \\
\end{array}$ & 4085 & -689.3 & 550 \\
\hline F18 & 561.0 & -3 & 36.9 & \begin{tabular}{|c|}
-11 \\
\end{tabular} & 0.0 & 0 \\
\hline F19 & 389.3 & 0 & 20.4 & 162 & -13.1 & -23 \\
\hline F20 & 499.6 & 0 & 0.0 & 0 & 0.0 & 0 \\
\hline F21 & 453.0 & -13 & -49.1 & 54 & -31.7 & -13 \\
\hline F22 & 255.8 & 0 & 0.0 & 0 & 0.0 & 0 \\
\hline F23 & 631.5 & -1 & 0.0 & 0 & -160.6 & 46 \\
\hline F24 & 461.8 & 5 & -1.0 & $\begin{array}{l}-114 \\
\end{array}$ & 30.3 & 1493 \\
\hline F25 & 357.1 & 9 & 10.3 & 882 & -69.2 & 31 \\
\hline F26 & 245.5 & 31 & 7.9 & 0 & 0.0 & 0 \\
\hline F27 & 529.5 & -7 & 416.7 & 489 & -327.3 & 188 \\
\hline F28 & 438.6 & 8 & -32.5 & 257 & 0.0 & 0 \\
\hline F29 & 338.8 & 27 & 0.0 & 0 & 0.0 & 0 \\
\hline F30 & 462.3 & -5 & 0.0 & 0 & 0.0 & 0 \\
\hline F31 & 1055.3 & 19 & 0.0 & 0 & -90.5 & -19 \\
\hline F32 & 1022.4 & -10 & 0.0 & 0 & 37.8 & 18 \\
\hline F33 & 628.9 & 6 & 0.0 & 0 & 247.5 & -233 \\
\hline F34 & 223.0 & 15 & 0.0 & 0 & 0.0 & 0 \\
\hline F35 & 334.5 & $\begin{array}{ll}-11 \\
\end{array}$ & 0.0 & 0 & -22.4 & -9 \\
\hline F36 & 631.6 & 8 & 0.0 & 0 & 0.0 & 0 \\
\hline F37 & 630.0 & 0 & 0.0 & 0 & -8.6 & -94 \\
\hline F38 & 463.9 & 13 & 0.0 & 0 & 0.0 & 0 \\
\hline F39 & 235.7 & 12 & 0.0 & 0 & 12.1 & -457 \\
\hline F40 & 297.5 & 12 & 0.0 & 0 & 26.2 & 777 \\
\hline F41 & 689.6 & -4 & 4.5 & -74 & 0.0 & 0 \\
\hline F42 & 755.5 & 2 & 0.0 & 0 & 0.0 & 0 \\
\hline F43 & 916.6 & -2 & 0.0 & 0 & \begin{tabular}{|l|}
-83.4 \\
\end{tabular} & -85 \\
\hline F44 & 544.6 & 0 & 97.6 & 21 & -114.5 & 54 \\
\hline F45 & 585.5 & -8 & -67.0 & 823 & 0.0 & 0 \\
\hline F46 & 699.4 & -14 & $\begin{array}{l}-79.0 \\
\end{array}$ & 956 & -46.8 & -13 \\
\hline F47 & 1040.7 & -10 & 263.5 & 97 & 35.0 & 1 \\
\hline Total & 26185.8 & - & - & - & - & - \\
\hline Average & - & 9 & - & 196 & - & 203 \\
\hline
\end{tabular}




\section{Table 12}

Settlement for simplified models - $\mathrm{mm}$

\begin{tabular}{|c|c|c|c|c|c|c|c|c|c|}
\hline Found. & Mixed SSI & Differ. (\%) & Mixed SIMP & Differ. (\%) & Found. & Mixed SSI & Differ. (\%) & Mixed SIMP & Differ. (\%) \\
\hline F01 & 4.2 & -2 & 3.4 & -21 & F24 & 9.5 & 2 & 9.6 & 3 \\
\hline F02 & 5.1 & -4 & 5.1 & -5 & F25 & 5.9 & -1 & 6.1 & 2 \\
\hline F03 & 10.2 & 7 & 9.9 & 4 & F26 & 8.7 & 2 & 9.5 & 12 \\
\hline F04 & 11.2 & 4 & 11.1 & 3 & F27 & 4.3 & 5 & 3.6 & -11 \\
\hline F05 & 6.0 & -4 & 5.8 & -9 & F28 & 5.6 & 1 & 5.7 & 3 \\
\hline F06 & 8.3 & 0 & 8.5 & 2 & F29 & 8.7 & 1 & 9.8 & 14 \\
\hline F07 & 5.0 & -3 & 5.4 & 5 & F30 & 9.9 & 4 & 9.4 & -2 \\
\hline F08 & 5.3 & -3 & 5.9 & 7 & F31 & 6.7 & 1 & 7.4 & 11 \\
\hline F09 & 10.0 & 6 & 10.5 & 12 & F32 & 7.6 & 2 & 7.2 & -4 \\
\hline F10 & 10.5 & 7 & 11.1 & 12 & F33 & 4.3 & 3 & 4.7 & 11 \\
\hline F11 & 4.2 & -2 & 5.7 & 33 & F34 & 5.6 & 0 & 6.2 & 11 \\
\hline F12 & 5.3 & -3 & 5.8 & 5 & F35 & 8.2 & 2 & 7.7 & -5 \\
\hline F13 & 9.8 & 6 & 10.4 & 12 & F36 & 9.4 & -1 & 9.7 & 3 \\
\hline F14 & 10.9 & 6 & 10.8 & 5 & F37 & 6.4 & -4 & 6.8 & 2 \\
\hline F15 & 6.2 & -3 & 6.0 & -5 & F38 & 5.3 & 1 & 5.8 & 10 \\
\hline F16 & 7.9 & -1 & 8.5 & 6 & F39 & 5.8 & 2 & 6.3 & 10 \\
\hline F17 & 4.1 & -2 & 3.4 & -19 & F40 & 7.8 & 1 & 7.7 & 0 \\
\hline F18 & 5.2 & -3 & 5.1 & -6 & F41 & 8.2 & 3 & 7.8 & -1 \\
\hline F19 & 9.3 & 1 & 9.2 & 0 & F42 & 6.0 & -2 & 6.3 & 3 \\
\hline F20 & 10.6 & 4 & 10.1 & -1 & F43 & 7.0 & -4 & 7.3 & 0 \\
\hline F21 & 5.7 & -2 & 5.3 & -8 & F44 & 4.2 & 4 & 4.1 & 4 \\
\hline F22 & 8.5 & 3 & 8.5 & 4 & F45 & 5.4 & 2 & 5.2 & -3 \\
\hline F23 & 5.0 & 0 & 4.2 & -17 & F46 & 7.5 & 7 & 6.3 & -10 \\
\hline- & - & - & - & - & F47 & 8.2 & -4 & 7.5 & -12 \\
\hline
\end{tabular}

trend towards the standardization of settlements. The maximum differential settlement and the maximum absolute settlement showed a marked reduction. The mean settlement, however, was not very influenced.

The soil-structure interaction provided a redistribution of the loads in the foundations and a significant reduction of the applied moments. As a general rule, there was a load transfer from foundations with higher settlements to the neighbouring foundations of lower settlements.

There were important changes in the normal stresses of the walls. The greatest influence of the soil-structure interaction occurred on the first floors, where there were differences greater than $18 \%$, adopted as an acceptable limit in this work.

The simplified models adequately represented the stress flow on the walls and the load distribution on the foundations. The MIXED SSI model presented the best results.

\section{Table 13}

Supplementary information on simplified model settlements

\begin{tabular}{|c|c|c|c|c|}
\hline Information & $\begin{array}{c}\text { Mixed } \\
\text { SSI }\end{array}$ & $\begin{array}{c}\text { Differ. } \\
\text { (\%) }\end{array}$ & $\begin{array}{c}\text { Mixed } \\
\text { SIMP }\end{array}$ & $\begin{array}{c}\text { Differ. } \\
\text { (\%) }\end{array}$ \\
\hline Maximum settlement (mm) & 11.2 & 4 & 11.1 & 3 \\
\hline $\begin{array}{c}\text { Maximum differential } \\
\text { settlement (mm) }\end{array}$ & 7.1 & 5 & 7.7 & 15 \\
\hline Average settlement (mm) & 7.1 & 1 & 7.2 & 2 \\
\hline Coefficient of variation (\%) & 30 & 7 & 31 & 9 \\
\hline
\end{tabular}

\section{Acknowledgments}

The authors gratefully acknowledge CNPq (National Council for Scientific and Technological Development ) for the financial support.

\section{References}

[1] NUNES, V. Q. G. Análise estruturais de edifícios de paredes de concreto armado, São Paulo, 2011, DSSlertação (Mestrado) - Escola de Engenhari de São Carlos, Universidade de São Paulo (in Portuguese).

[2] BRAGUIM, T. C. Utilização de modelos de cálculo para projetos de edifícios de paredes de concreto armado moldadas no local, São Paulo, 2013, DSSlertação (Mestrado) - Escola Politécnica, Universidade de São Paulo (in Portuguese).

[3] ASSOCIAÇÃO BRASILEIRA DE NORMAS TÉCNICAS. Paredes de concreto moldadas no local para construção de edificações. - NBR 16055, Rio de Janeiro, 2012 (in Portuguese).

[4] MEYERHOF, G. G. Some recent foundation research and its application to design. Structural Engineering, v.31, n.2, 1953; p.151-167.

[5] CHAMECKI, S. Structural rigidity in calculating settlements. Journal of Soil Mechanics and Foundation Division, v.82, n.SM-1, 1956; p.1-19.

[6] GOSHY, A. D. Soil-foundation-structure interaction. Journal of Structural the Division, v.104, 1978; p.749-761. 
[7] GUSMÃO, A. D. Aspectos relevantes da interação solo-estrutura em edificações. Solos e Rochas, v.17, 1994; p.47-55 (in Portuguese).

[8] TESTONI, E. Análise estrutural de edifícios de paredes de concreto por meio de pórtico tridimensional sobre apoios elásticos, São Paulo, 2013, DSSlertação (Mestrado) - Escola de Engenharia de São Carlos, Universidade de São Paulo (in Portuguese).

[9] TESTONE, E. Análise de interação solo-estrutura em edifícios de paredes de concreto moldadas no local. Revista Fundações e Obras Geotécnica, v.6, 2016; p.36-46 (in Portuguese).

[10] SANTOS, M. G C. Análise estrutural dos efeitos dos deslocamentos dos apoios de edifícios de paredes de concreto moldadas no local, São Paulo, 2016, DSSlertação (Mestrado) - Escola de Engenharia de São Carlos, Universidade de São Paulo (in Portuguese).

[11] LIU, Y. P. et al. Second-order Analysis and design of wallframed structures allowing for imperfections. Advances in Structural Engineering, v.13, n.3, 2010; p.513-524.

[12] YAGUI, T. Estruturas constituídas de paredes delgadas com diafragmas transversais, São Paulo, 1971, Tese (Doutorado) - Escola de Engenharia de São Carlos, Universidade de São Paulo (in Portuguese).

[13] YAGUI, T. Análise de estruturas de edifícios construídas de núcleos de concreto armado e pilares ou pendurais de aço (carregamento crítico de instabilidade), São Paulo, 1978, Tese (livre-docência), Universidade de Campinas (in Portuguese).

[14] CORRÊA, M. R. S. Aperfeiçoamento de modelos usualmente empregados no projeto de sistemas estruturais de edifícios, São Paulo, 1991, Tese (Doutorado) - Escola de Engenharia de São Carlos, Universidade de São Paulo (in Portuguese).

[15] NASCIMENTO NETO, J. A. Investigação das solicitações de cisalhamento em edifícios de alvenaria estrutural submetidos a ações horizontais, São Paulo, 1999, DSSlertação (Mestrado) - Escola de Engenharia de São Carlos, Universidade de São Paulo (in Portuguese).

[16] AOKI, N. Aspectos geotécnicos da interação estruturamaciço de solos. In: XXVIII Jornadas Sul-Americanas de Engenharia Estrutural, São Carlos, 1997, Anais, São Carlos, 1997 (in Portuguese).

[17] MINDLIN, R. D. Force at a point in the interior of a semiinfinite solid. Physics, v.7, 1936; p.195-202.

[18] STEINBRENNER, W. Tafeln zur setzungsberechnung. Die Strasse, v.1, 1934; p.121.

[19] REIS, J. H. C. Interação solo-estrutura de grupo de edifícios com fundações superficiais em argila mole, São Paulo, 2000, DSSlertação (Mestrado) - Escola de Engenharia de São Carlos, Universidade de São Paulo (in Portuguese).

[20] ASSOCIAÇÃO BRASILEIRA DE NORMAS TÉCNICAS. Cargas para o cálculo de edificações. - NBR 6120, Rio de Janeiro, 1980 (in Portuguese).

[21] ASSOCIAÇÃO BRASILEIRA DE NORMAS TÉCNICAS. Ações e segurança nas estruturas - procedimento. - NBR 8681, Rio de Janeiro, 2003 (in Portuguese). 